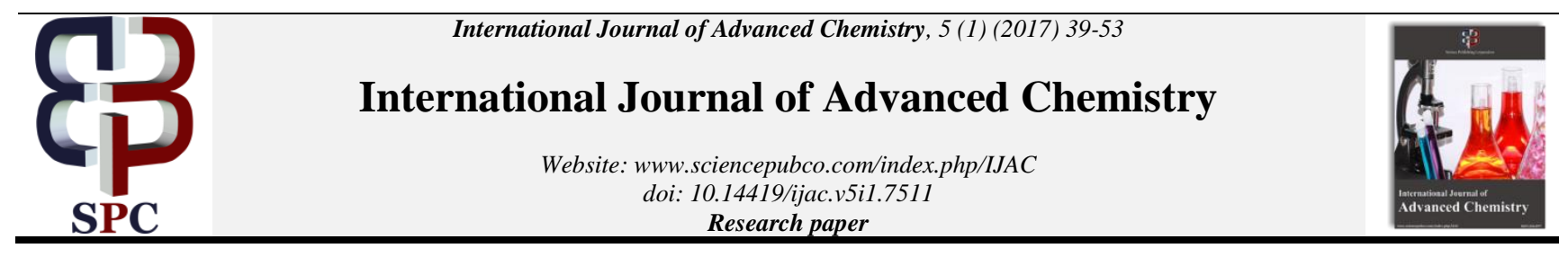

\title{
Gas chromatography-mass spectral structural analysis, phytochemical screening and antimicrobial activity of n-hexane leaf extract of Corymbia torelliana
}

\author{
Daben Janet Moses ${ }^{1 *}$, Dashak Dayil Albert ${ }^{2}$, Isaac Rahab Uwhomagbejo ${ }^{2}$ \\ ${ }^{1}$ Department of Science Laboratory Technology, Faculty of Natural Sciences, University of Jos, P M B. 2084, Jos, \\ PlateauState, Nigeria \\ ${ }^{2}$ Department of Chemistry, Faculty of Natural Sciences,University of Jos, P M B. 2084, Jos, Plateau State, Nigeria \\ *Corresponding author E-mail: dabenjanet@yahoo.co.uk
}

\begin{abstract}
The chemical studies and antimicrobial activity of n-hexane leaf extract of Corymbiatorelliana was evaluated for medicinal importance. The phytochemical constituents present were steroids, tannins, cardiac glycosides alkaloids and terpenes. The result of sodium fussion test revealed the presence of Phosphorus Nitrogen and Chlorine. The Column Chromatography gave several fractions that were pulled together by Thin Layer Chromatography based on their Rf values, colours and resolutions on different solvent systems. GC-MS was used to identify compounds like: Hexadecanoic acid methyl ester, 9,12-Octadecadienoic acid methyl ester, 2,2,4,4-tetramethyl-1,3-cyclobutanediene, Pentadecanoic acid-14-methyl methyl ester, Hexadecanoic acid-2-hydroxyl propyl ester, 2(4H)-Benzofuranone-5,6,7,7a-tetrahydro-4,4,7a-trimethyl and many others. Antimicrobial screening was carried out on Escherichia coli, Staphylococcus aureus and Aspergillus niger using the agar well diffusion technique. The result shows that the extract exhibit antimicrobial activity with zones of inhibition in diameter. These results show that the plant exhibit antimicrobial activity and possess pharmacological characteristics, which could be applied in the production of potent drugs.
\end{abstract}

Keywords: Antimicrobial Activity; Corymbia torelliana; Sodium Fusion Test; Gas Chromatography-Mass Spectometry; Phytochemical Screening.

\section{Introduction}

Man has learned to search for drugs in fruits, seeds, barks, leaves and other parts of plants due to many years of struggle against illness. Medicinal plants have shown great promises as sources of easily available effective therapy for diseases particularly tropical developing country (Roopashree et al. 2009, p. 20). Africa and indeed Nigeria has large collection of these plants and herbs that are of medicinal importance. The total combination of knowledge and traditional practices used in diagnosing, eliminating or preventing ailment, which may rely exclusively on experiences, verbally, or written as used to define traditional medicine by WHO (2002) has intensified scientific search and recovery of new metabolites from traditional and medicinal plants.

Phytochemistry or plant chemistry studies of flora cannot be exhausted, but has followed since the beginning of exploration and therefore developed alongside the growth in sciences of chemistry as a distinct discipline (Harborne 1984, p. 1). Thin Layer Chromatography (TLC) serves as one of the many analytical methods in providing a chromatographic plant extract fingerprint (Azra et al. 2012, p. 146). The extraction of bioactive agent from plants is one of the most appealing areas among scientists and non-scientists alike today because of the emergence of bacterial resistance like Pseudomonas aeruginosa with its ability to rapidly develop resistance to multiple classes of antibiotic is still lingering (Lister et al. 2009, p. 583).
Corymbia torelliana has found familiarization in the area of research due to its diverse applications in areas of traditional medicine. The essential oils of the plant parts are rich in natural compounds such as hydrocarbon monoterpenol, spatulenol, $\alpha$ and $\beta$ pinenes, ocimene, aromadendrene and caryophyllene oxide as its characteristic constituents (Alian et al. 2012, p. 6). Dashak \& his co-workers (2016, p.59) have reported that the essential oils of the fruits contained compounds, which could be use as fragrance in manufacturing industries.

In Nigeria, $C$. torelliana leaves have been known as curative agent for sore throat, bacterial infections of respiratory and urinary tract, wounds, gastric and duodenal ulcers and cough associated with most pulmonary diseases (Farah et al. 2002, p. 395; Adeniyi et al. 2006; p. 34, Alian et al. 2012, p. 6).

In many developing countries, particularly in Africa these plants at present are used in local traditional medicine and above all reputed as having useful medicinal activities. Some of which has been proven by researches as alternatives to improved drugs. These plants can provide basis for establishing of local pharmaceutical industries where new substances or drugs could be synthesized for use against diseases for which suitable cures are found or not yet available.

This work assesses the activities of the n-hexane extract from the leaves of Corymbia torelliana on Escherichia coli, Staphylococcus arueus and Aspergellus niger micro-organisms. The results of the secondary metabolites will suggest the types of bioactive natural products, and the GCMS analysis will proffer headway to the 
compounds that might be responsible for the activities of the leaves extract.

\section{Materials and methods}

\subsection{Collection and preparation of plant sample}

The fresh leaves of the plant were obtained from the plantation in Ishong Agwom community, Furaka Road, Plateau State, Nigeria. It was authenticated and deposited in the Herbarium, with a Voucher No. FHJ 028 in the Department of Horticulture, Federal College of Forestry, Jos, Plateau State, Nigeria. The leaves samples were stored in plastic containers and brought into the laboratory after which was cleaned, air dried under shade, milled and stored for analysis.

\subsection{Extraction and eoncentration of extract}

The pulverizes leaf through sample weighing $130 \mathrm{~g}$ was extracted with n-hexane by reflux (soxhlet) methods. The extracts were concentrated by vacuum rotary evaporator (R-205) at $35 \mathrm{oC}$, and stored in an air tight container for further analysis.

\subsection{Column chromatography analysis}

The slurry was prepared using $150 \mathrm{~g}$ of silica gel (200-400 mesh) in $500 \mathrm{ml}$ ethyl acetate and was gently poured into the column, ensuring no air bubbles were trapped. The packed column was allowed to settle evenly. $5 \mathrm{~g}$ of the crude extract was dissolved in $10 \mathrm{ml}$ of ethyl acetate, which was then adsorbed on $20 \mathrm{~g}$ of the silica gel (200-400 mesh) and then placed on the column. The height of the mobile phases above the packed column was $5-10 \mathrm{~cm}$ (Thomas 1975, p. 92). The flow rate of the mobile phase in the column was kept constant. The effluent was collected in small fraction of $\left(50 \mathrm{~cm}^{3}\right)$ in a beaker, so that the separated compounds on the column remain resolved. The $n$-hexane extract was separated using n-hexane, ethyl acetate and methanol mobile phases in ratios and several fractions were obtained.

\subsection{Thin layer chromatography analysis}

The dried prepared plates were spotted with the fractions from Column Chromatography of the $\mathrm{n}$ - hexane extracts. The extracts were spotted in duplicate at equal distances of $1.5 \mathrm{~cm}$ to each other and allowed to dry. The plate was transferred into a developing tank already saturated with the mobile phases (chloroform, methanol) in ratios $(9: 1,4: 1,3: 1)$ for all the fractions. Chromatograms were observed under uv-light $254 \mathrm{~nm}$ and separated components were viewed, circled and Rf values calculated, based on this, the fractions were pooled together (Harborne1984, p. 11). The pooled fractions 1,2 and 3 were analyzed by GC-MS analysis.

\subsection{Gas chromatography and mass-spectrophotometer analysis}

Analysis of the leaves of Corymbia torelliana using Gas Chromatography and Mass-Spectrophotometer (Shimadzuma Japan QP2010 PLUS); under the following conditions: AOC-20i autoinjection, column flow rate $1.58 \mathrm{ML} / \mathrm{min}$, injection volume of $1 \mu \mathrm{L}$ at $2500 \mathrm{C}$ with initial temperature of column at $800 \mathrm{C}$, pressure of $108 \mathrm{pKa}$, total flow of $6.2 \mathrm{~mL} / \mathrm{min}$ and total run time- $28 \mathrm{mins}$. Carrier gas Helium at a constant flow rate of $0.99 \mathrm{ml} / \mathrm{min}$.

\subsection{Identification of GC-MS chromatograms}

Identification of leaves chromatograms were compared with published Electron Impact-Mass Spectral (EI-MS) in the NIST (National Institute of Standards of Technology), Shimadzu's Flavours and Fragrance of Natural Synthetic Compounds (FFNSC), and published spectral data. The retention indices were determined based on a homologous series of n-alkanes internal standard analyzed under the same operating conditions. Calibration based on the Automatic Adjustment of Compound Retention Time (AACRT) function of the GC-MS. Relative concentration of the leaves extract component were calculated based on GC peak area with computer matching using NIST libraries provided with computer controlling the GC-MS System. The spectrum of unknown component was compared with the spectrums of known components stored in the libraries. The name, molecular weight and structure of the components of the test materials ascertained (Silverstein et al. 1974, p. 41-71. Lee 1998, p. 1-21).

\subsection{Phytochemical screening}

The extract was screened for the presence of these secondary metabolites: saponins, tannins, cardiac glycosides, anthraquinones, flavonoids, alkaloids, terpenes, and steroids.

\subsubsection{Test for saponins}

The frothing tests (Wall et al.1954, p. 1-7).

\subsubsection{Test for tannins}

Reduction test (Trease \& Evans 1989, p. 244-248).

\subsubsection{Test for cardiac glycosides}

Keller Killiani test. (Trease \& Evans 1989)

\subsubsection{Test for anthraquinones}

Bourntrager's test and Liebermann Burchard (Trease\& Evans 1989)

\subsubsection{Test for alkaloids}

Mayer's Reagent and Picric acid test (Trease \& Evans 1989).

\subsubsection{Test for terpenes and steroids}

Salkowski test (Sofowora 1982, p. 54-56).

\subsubsection{Test for flavonoid}

Lead acetate test and Sodium hydroxide test (Segelman et al. 1971, p. 52-55).

\subsection{Sodiumfussion (lassaigne) test}

Sodium fussion (Lassaigne) Test was used in elemental analysis for the qualitative determination of the presence of Halogens, Nitrogen, Sulphur and Phosphorus. The leaves sample was fused with sodium metal then plunged into water and qualitative analysis were carried out on the resultant solution to obtain various constituents (Vishnoi 1979, p. 40-42).

\subsection{Test organisms and their preparations}

Escherichia coli, Staphylococcus arueus and Aspergillus niger were obtained from the Department of Microbiology, University of Jos, Plateau State, Nigeria. The bacterial were kept on nutrient Agar (NA) slant at $4^{\circ} \mathrm{C}$. Inoculations were obtained from overnight culture grown on NA slant at $37^{\circ} \mathrm{C}$.

\subsection{Determination of anti-bacterial activity}

Agar well diffusion method as described by (Sanchez et al. 2005, p.430-431 ) was use for the antibacterial screening. $0.9 \mathrm{~g}$ of the crude extract was dissolved in $9 \mathrm{~cm}^{3}$ of distilled water to obtain $90 \mathrm{mg} / \mathrm{cm}^{3}$ as the highest stock solution. It was then serially diluted using the procedures of (Atlas 1995, p.765, Ochei \& Kochatkar 2007 , p. 795-817) Gentamycin at $4 \mathrm{mg} / \mathrm{cm}^{3}$ was included as posi- 
tive control. The sterilized molten nutrient Agar at $45^{\circ} \mathrm{C}$ was set on the disinfected plates and equidistant wells on the surfaces of the agar were bored using a sterile cork borer of $4 \mathrm{~mm}$ diameter. $0.2 \mathrm{ml}$ of prepared extracts of different concentrations as well as the standard drug was transferred into the made holes of the agar. The culture plates were allowed to stand for 30mins for prediffusion and the bacterial were incubated for 24 hours at $37^{\circ} \mathrm{C}$ after which the zone of inhibition were measured.

\subsection{Determination of Minimum Inhibition Concentration. (MIC)}

A double dilution of the extracts solutions $90 \mathrm{mg} / \mathrm{ml}, 45 \mathrm{mg} / \mathrm{ml}$ $22.5 \mathrm{mg} / \mathrm{ml}, 11.25 \mathrm{mg} / \mathrm{ml}$ were prepared in the nutrient broth accurate volume of $0.1 \mathrm{ml}$ of the suspension of an overnight culture of the test bacterial were added to respective sets of the test tube. After shaking to mix, the test tube were incubated at $37^{\circ} \mathrm{C}$ for 24hours in an incubator. The test tubes were examined for turbidity. The presence of the turbidity indicated growth in the test bacterial. The highest concentration that inhibited visible growth of the bacterial was observed and recorded as Minimum Inhibitory Concentration (MIC) of the extracts for that particular organism. The test was conducted under aseptic conditions.

\subsection{Determination of minimum bactericida concentration (MBC)}

The Minimum Bactericidal Concentration of the extracts that eliminate the test bacteria is known as Minimum Bactericidal Concentration. This is done in sub-culturing the contents of the test tubes that shows no growth in the (MIC) determination. Subculturing was done by streaking of loopful of the required MIC test tubes over the surface of the already set agar. This was incubated overnight at $37^{\circ} \mathrm{C}$ for 24 hours. The MBC was recorded as the lowest concentration with no growth observed on the nutrient agar plates.

\section{Results and discussion}

This research work has presented the phytochemical, elemental, antimicrobial activity and Gas Chromatography-Mass Spectrometry analysis in Tables 1-6.

Table 1 shows phytochemical components of $n$-hexane leaf extract of $C$. torellaina. The result revealed the presence of tannins, steroids, cardiac glycosides, alkaloids and terpenes while other components are absent. These secondary metabolites are vital to its medicinal values and physiological activity. Tannins are essential in invitro protein digestion while Steroids are associated with compounds used as sex hormones. Alkaloids contribute to plant fitness and survival often have pharmacological effects and are used in medicine so also terpenes are recognized for their aromatic qualities (Bwai et al. 2014, p. 179). The presence of alkaloids in the leaf extract as obtained in this research work does not contained in the methanolic extract of the leaf as earlier determined by (Ogbole et al. 2016, p. 24, Adeniyi and Ayepola 2008, p. 34). However, saponins, anthraquinones and flavonoids have been reported present from the same authors as against this work even though no n-hexane leaf extract study have been reported. The reasons could be due to several factors such as solvent, climate, habitant, soil nutrients, time of harvest, stress and physiological age of the plant. (Vagahasiya 1997, p. 754, Glasby 1999, p. 125) had reported that the eucalyptus species contain a variety of phytoconstituents that are effective in the treatment of ulcer.

The result of Sodium fusion test in table 2 indicate the presence of nitrogen, phosphorous and chlorine in the plant, which agree with the compounds identified by the GC-MS spectral analysis and supportedby other earlier authors (Alianet al. 2012, p. 10, Ololade and Olawore 2013, p. 6-8) as constituents of the leaves plant extract.

\subsection{Phytochemical screening}

Table 1: Phytochemical Constituents of the Leaf Extract of Corymbia torelliana

\begin{tabular}{lc}
\hline Phytochemical components & Leaf extract \\
\hline Saponins & - \\
Alkaloids & + \\
Tannins & + \\
Anthraquinones & - \\
Flavonoids & - \\
Cardiac glycosides & + \\
Steroids & + \\
Terpenes & + \\
\hline
\end{tabular}

Note: $+=$ Present $-=$ Absent

\subsection{Sodium fusion test}

Table 2: Sodium/ Lassaigne's Test for S, N, P and the Halogens

Test $\quad$ Observation
$2 \mathrm{~cm}^{3}$ of sample filtrate + conc. Yellow ppt soluble in aq. $\mathrm{NH}_{3}$ Phosphorus
present
$\mathrm{HNO}_{3}\left(0.5 \mathrm{~cm}^{3}\right)+5 \%$ solution
+ ammoniummolybdate + heat
Filtrate + sodium nitroprussideNocolour change Sulphur absent
Solution
Filtrate $+\mathrm{FeSO}_{4}+$ dil. $\mathrm{NaOH}$ Green heavy ppt observed
solution + heat
Cooled + dil. $\mathrm{H}_{2} \mathrm{SO}_{4}$ Iron (ii) hydroxide obtained Nitrogen present
Filtrate + excess dil. $\mathrm{HNO}$ No visible colour change Iodine absent
$+\mathrm{HgCl}$
Filtrate + dil. $\mathrm{HNO}_{3}$ White clear solution Chlorine suspected
Solution $+\mathrm{NH}_{3} \mathrm{White} \mathrm{ppt} \mathrm{soluble} \mathrm{in} \mathrm{Chlorine} \mathrm{present}_{\text {Aq. } \mathrm{NH}}$

\subsection{Antimicrobial screening}

Table 3: Antimicrobial Activity of N-Hexane Leaf Extract of Corymbiatorelliana

Concentrations $\left(\mathrm{mg} / \mathrm{cm}^{3}\right)$ Control
Organisms $904522.511 .25 \quad 4\left(\mathrm{mg} / \mathrm{cm}^{3}\right)$
Escherichia coli $15 \pm 0.41 \quad 14 \pm 0.2612 \pm 0.08 \quad 10 \pm 0.06 \quad 26 \pm 1.02$
Staphylococcus $18 \pm 0.4614 \pm 0.23 \quad 13 \pm 0.7010 \pm 0.08 \quad 32 \pm 0.63$
Aureus
Aspergillus - - --
Niger
Key: $-=$ No inhibition $+=$ inhibition $\pm=$ SEM

Table 4: Minimum Inhibitory Concentration (MIC) of corymbiatorelliana Leaves Extract

Concentrations $\left(\mathrm{mg} / \mathrm{cm}^{3}\right)$

Organisms 904522.511 .25

Escherichia - - -

Coli

Staphylococcus- - - +

Aureus

Aspergillus -...

Niger

Key: $-=$ No inhibition $+=$ inhibition

Table 5: Minimum Bacteriocidal Concentration (MBC) of Corymbiatorelliana Leavesextract

Concentrations $\left(\mathrm{mg} / \mathrm{cm}^{3}\right)$

Organisms 904522.511 .25

Escherichia - - - +

Coli

Staphylococcus - - - +

Aureus

Aspergillus- - - -

Niger

Key: $-=$ No inhibition $+=$ inhibition

Tables 3-5 presents the antimicrobial activity of the leaf extract against Escherischia coli, (gram negative), Staphylococcus aureus (gram positive) and Aspergillus niger (fungi).

Table 3 shows the effect of the leaf extract on the test organisms. The results demonstrated that the extract inhibited the growth of $\mathrm{E}$. coli and S. aureus but below the control. There was no inhibited 
growth of A. niger at the concentration used, this could be attributed to the action of phyto-constituents of the plant (Ayepola and Adeniyi 2008, p. 38) such as the terpenes may be responsible, for it is known not to possess the possibility to attack, to link up the membrane cell and to destroyed it (Alain et al. 2012, p. 9).

The MIC result of $n$-hexane leaf extract is presented in Table 4. Aspergillus niger and E. coli represent poor activity as agreed with the earlier work of (Alain et al.2012, p. 9) on the essential oil of the leaves by hydro-distillation method but against the methanol and dichloromethane extracts reported by (Adeniyi and Ayepola, 2008 , p. 38). The n-hexane leaf extract activity on S. aureus is effective at $11.25 \mathrm{mg} / \mathrm{ml}$ and below. The $\mathrm{MBC}$ result in Table 5 shows that the concentration of the extract that prevents the activity of the bacteria is $11.25 \mathrm{mg} / \mathrm{ml}$.

The antimicrobial activities demonstrated by the crude extract of n-hexane is of utmost significance since both gram negative and gram positive micro-organisms shows relative sensitivity on lower concentrations and possibly on higher concentration as suggested. These organisms were isolated from infected wounds, these results can justify the use of the plant in the treatment of wounds and hence the antibacterial and antifungal activities. Also, agreeing with the assertion of (Bruneton1999, p. 555-559) which stated that the decoction of the leaves of Corymbia torelliana could be used as a remedy for sore throat and bacterial infections

Table 6: Chemical Composition of the N-Hexane Leaves Extract of Corymbiatorelliana

\begin{tabular}{|c|c|c|c|c|}
\hline Compounds & $\begin{array}{l}\text { Mol. } \\
\text { Wt }\end{array}$ & Mol. For. & Molecular Structure & $\begin{array}{l}\text { R. } \\
\text { Time }\end{array}$ \\
\hline Hexadecanoic acid methyl ester & 270 & $\mathrm{C}_{17} \mathrm{H}_{34} \mathrm{O}_{2}$ & & 16.875 \\
\hline 9,12-Octadecadienoic acid methylester & 294 & $\mathrm{C}_{19} \mathrm{H}_{34} \mathrm{O}_{2}$ & & 19.875 \\
\hline $9,12,15$-Octadecatrienoic acid methyl ester & 292 & $\mathrm{C}_{19} \mathrm{H}_{32} \mathrm{O}_{2}$ & & 20.025 \\
\hline Octadecanoic acid methyl ester & 298 & $\mathrm{C}_{19} \mathrm{H}_{38} \mathrm{O}_{2}$ & & 20.317 \\
\hline 9,-Octadecenoic acid methyl ester & 296 & $\mathrm{C}_{19} \mathrm{H}_{36} \mathrm{O}_{2}$ & & 20.033 \\
\hline 2,2,4,4-tetramethyl-1,3-cyclobutanedione & 140 & $\mathrm{C}_{8} \mathrm{H}_{12} \mathrm{O}_{2}$ & & 5.458 \\
\hline Pentadecanoic acid-14-methyl methylester & 270 & $\mathrm{C}_{17} \mathrm{H}_{34} \mathrm{O}_{2}$ & & 16.875 \\
\hline $\begin{array}{l}\text { 2(4H)-Benzofuranone-5,6,7,7a tetrahydro-4,4,7a- } \\
\text { trimethyl }\end{array}$ & 180 & $\mathrm{C}_{11} \mathrm{H}_{16} \mathrm{O}_{2}$ & & 14.375 \\
\hline 6-Octadecenoic acid & 282 & $\mathrm{C}_{18} \mathrm{H}_{34} \mathrm{O}_{2}$ & & 20.825 \\
\hline Hexadecanoic acid-2-hydropropyl ester & 313 & $\mathrm{C}_{19} \mathrm{H}_{36} \mathrm{O}_{3}$ & & 22.408 \\
\hline Octadecanoic acid & 284 & $\mathrm{C}_{18} \mathrm{H}_{36} \mathrm{O}_{2}$ & & 20.350 \\
\hline Decene & 140 & $\mathrm{C}_{10} \mathrm{H}_{20}$ & & 5.458 \\
\hline Dodecene & 168 & $\mathrm{C}_{12} \mathrm{H}_{24}$ & & 5.817 \\
\hline $9,12,15$-hexadecatrienoic acid methyl ester & 264 & $\mathrm{C}_{17} \mathrm{H}_{28} \mathrm{O}_{2}$ & & 15.375 \\
\hline Phytol & 296 & $\mathrm{C}_{20} \mathrm{H}_{40} \mathrm{O}$ & & 21.017 \\
\hline Octadecanamide & 283 & $\mathrm{C}_{18} \mathrm{H}_{37} \mathrm{NO}$ & & 22.442 \\
\hline 9,12-heptadecadiene & 236 & $\mathrm{C}_{17} \mathrm{H}_{32}$ & & 11.517 \\
\hline 9,12,15-hexadecatrienoic acid & 250 & $\mathrm{C}_{16} \mathrm{H}_{26} \mathrm{O}_{2}$ & & 12.367 \\
\hline 9,12-Octadecadiene & 250 & $\mathrm{C}_{18} \mathrm{H}_{34}$ & & 15.367 \\
\hline 9,12-nonadecadienoic acid & 296 & $\mathrm{C}_{19} \mathrm{H}_{36} \mathrm{O}_{2}$ & & 19.908 \\
\hline Heneicosanoic acid methyl ester & 340 & $\mathrm{C}_{22} \mathrm{H}_{44} \mathrm{O}_{2}$ & & 21.000 \\
\hline Tricosanoic acid & 354 & $\mathrm{C}_{23} \mathrm{H}_{46} \mathrm{O}_{2}$ & & 22.450 \\
\hline
\end{tabular}




\subsection{GC-MS analysis, fragmentation patterns and mech-} anisms of some compounds

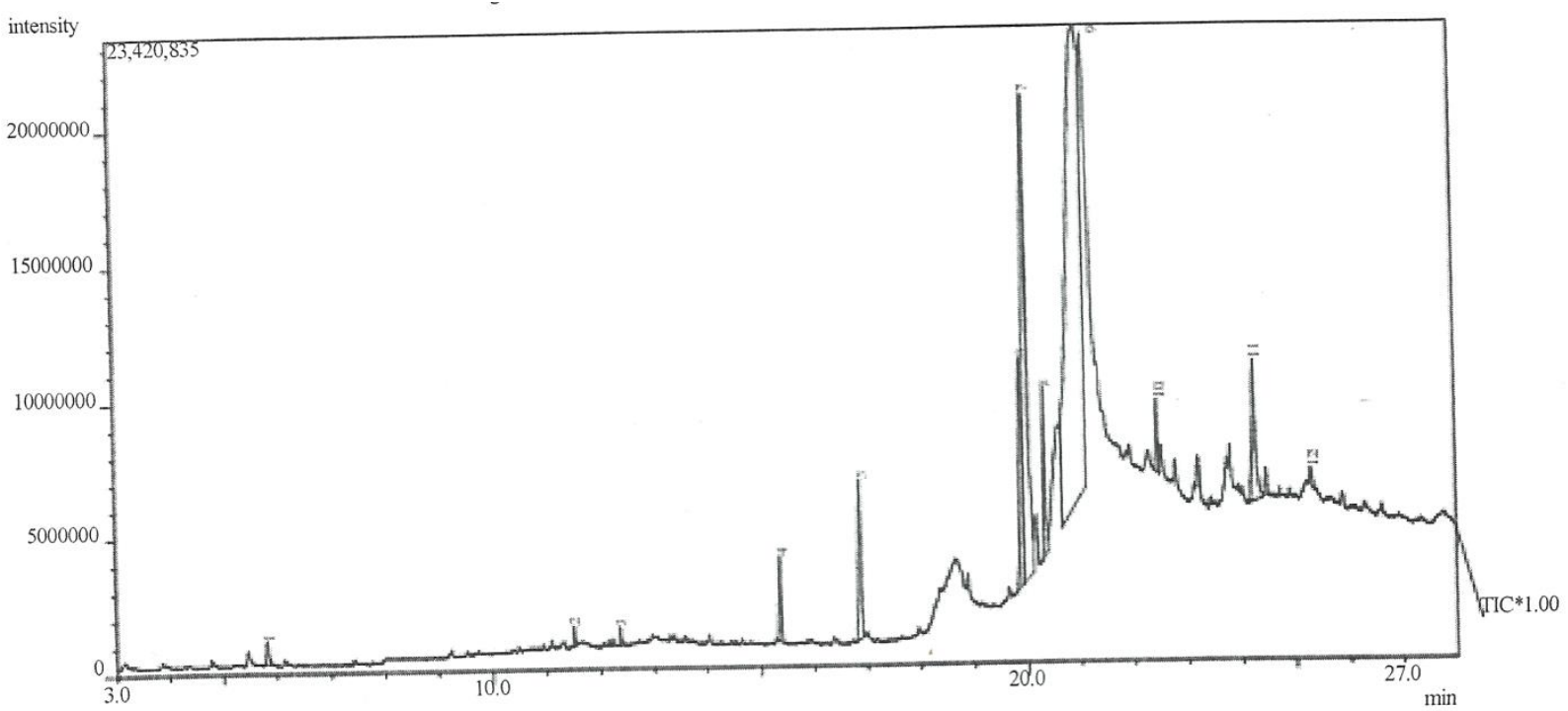

Fig. 1: GC-MS Chromatograms of N-Hexane Leaf Extract (Fraction 1).

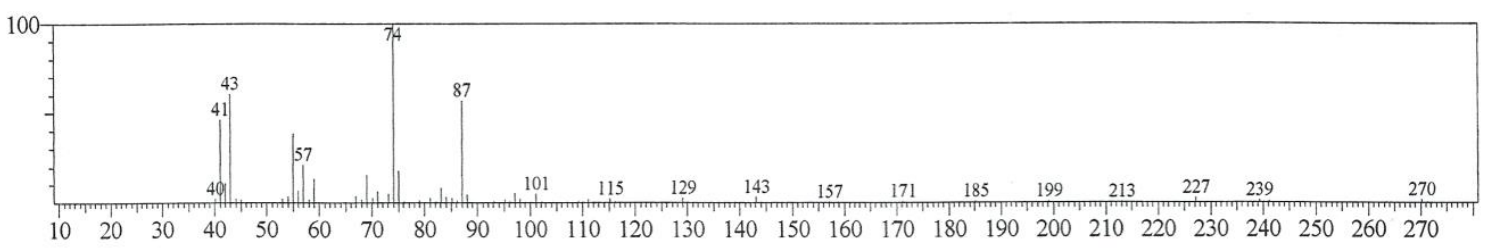

Fig. 2: Mass Spectrum of Peak 5 of Figure 1.

\subsubsection{Fragmentation pattern of hexadecanoic acid methyl} ester $\left(\mathrm{C}_{17} \mathrm{H}_{34} \mathrm{O}_{2}\right)$

The molecular structure of hexadecanoic acid methyl ester with the molecular weight of 270 as shown in the mass spectrum is shown below.

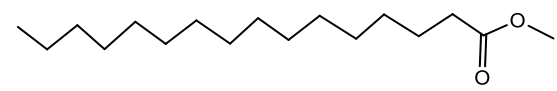

The structure could be rewritten as:

$\mathrm{CH}_{3}-\mathrm{CH}_{2}-\mathrm{CH}_{2}-\mathrm{CH}_{2}-\mathrm{CH}_{2}-\mathrm{CH}_{2}-\mathrm{CH}_{2}-\mathrm{CH}_{2}-\mathrm{CH}_{2}-\mathrm{CH}_{2}-\mathrm{CH}_{2}-\mathrm{CH}_{2}-\mathrm{CH}_{2}-\mathrm{CH}_{2}-\mathrm{CH}_{2}-\stackrel{\mathrm{C}}{\stackrel{\mathrm{C}}{-}-\mathrm{OCH}_{3}}$

The mass of each fragment lost and the mechanisms in the fragmentation pattern of Hexadecanoic acid methyl ester is describe below

Where there is a loss of methoxy group from an ion with $\mathrm{m} / \mathrm{z}$ of 270 , an ion with $\mathrm{m} / \mathrm{z}$ of 239 is form.

$\mathrm{CH}_{3}-\mathrm{CH}_{2}-\mathrm{CH}_{2}-\mathrm{CH}_{2}-\mathrm{CH}_{2}-\mathrm{CH}_{2}-\mathrm{CH}_{2}-\mathrm{CH}_{2}-\mathrm{CH}_{2}-\mathrm{CH}_{2}-\mathrm{CH}_{2}-\mathrm{CH}_{2}-\mathrm{CH}_{2}-\mathrm{CH}_{2}-\mathrm{CH}_{2}-\mathrm{C}_{\mathrm{O}}^{\mathrm{O}} \mathrm{OCH}$

Hexadecanoic acid methyl ester (molecular weight-m.wt270)

$\mathrm{CH}_{3}-\mathrm{CH}_{2}-\mathrm{CH}_{2}-\mathrm{CH}_{2}-\mathrm{CH}_{2}-\mathrm{CH}_{2}-\mathrm{CH}_{2}-\mathrm{CH}_{2}-\mathrm{CH}_{2}-\mathrm{CH}_{2}-\mathrm{CH}_{2}-\mathrm{CH}_{2}-\mathrm{CH}_{2}-\mathrm{CH}_{2}-\mathrm{CH}_{2}-\mathrm{C}$

Hexadecanal ion (m.wt 239)

When there a loss of methylene group and an addition of $2 \mathrm{H}$ ion, an ion with $\mathrm{m} / \mathrm{z}$ of 227 is obtain.

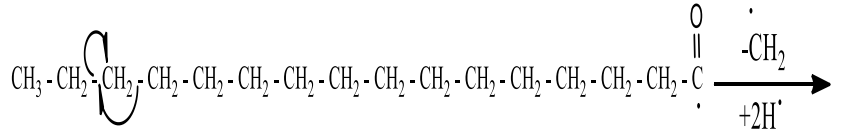<smiles>CCCCCCCCCCCCCCC=O</smiles>

Pentadecanol ion (m.wt 227)

After the consecutive loss of 10 molecules of methylene groups an ion with $\mathrm{m} / \mathrm{z}$ of 87 is form.

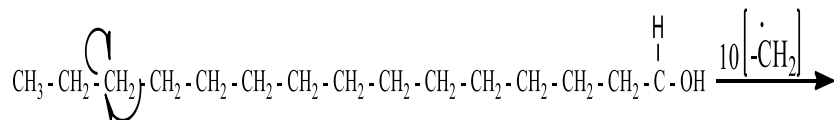

$\mathrm{CH}_{3}-\mathrm{CH}_{2}-\mathrm{CH}_{2}-\mathrm{CH}_{2}-\dot{\mathrm{C}} \mathrm{H}-\mathrm{OH}$

Pentanol ion (m.wt 87)

The loss of methylene group and addition of hydrogen ion will give a $\mathrm{m} / \mathrm{z}$ of 74

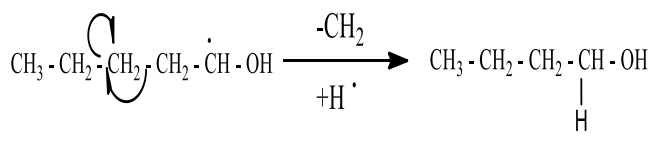

Butanol (m.wt 74)

The loss of hydroxyl group will bring about the formation of an ion with $\mathrm{m} / \mathrm{z}$ of 57 


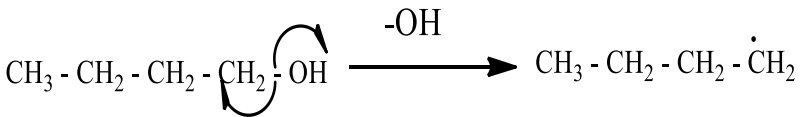

Butane ion (m.wt 57)

There a loss of a methylene group to obtain an ion with $\mathrm{m} / \mathrm{z}$ of 43

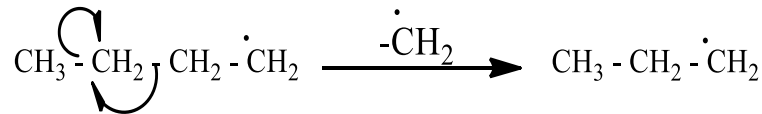

Propane ion (m.wt 43)

There is a loss of $2 \mathrm{H}$ and $\mathrm{H}$ that follows to form ions with $\mathrm{m} / \mathrm{z}$ of 41 and 40 (propene ions) respectively
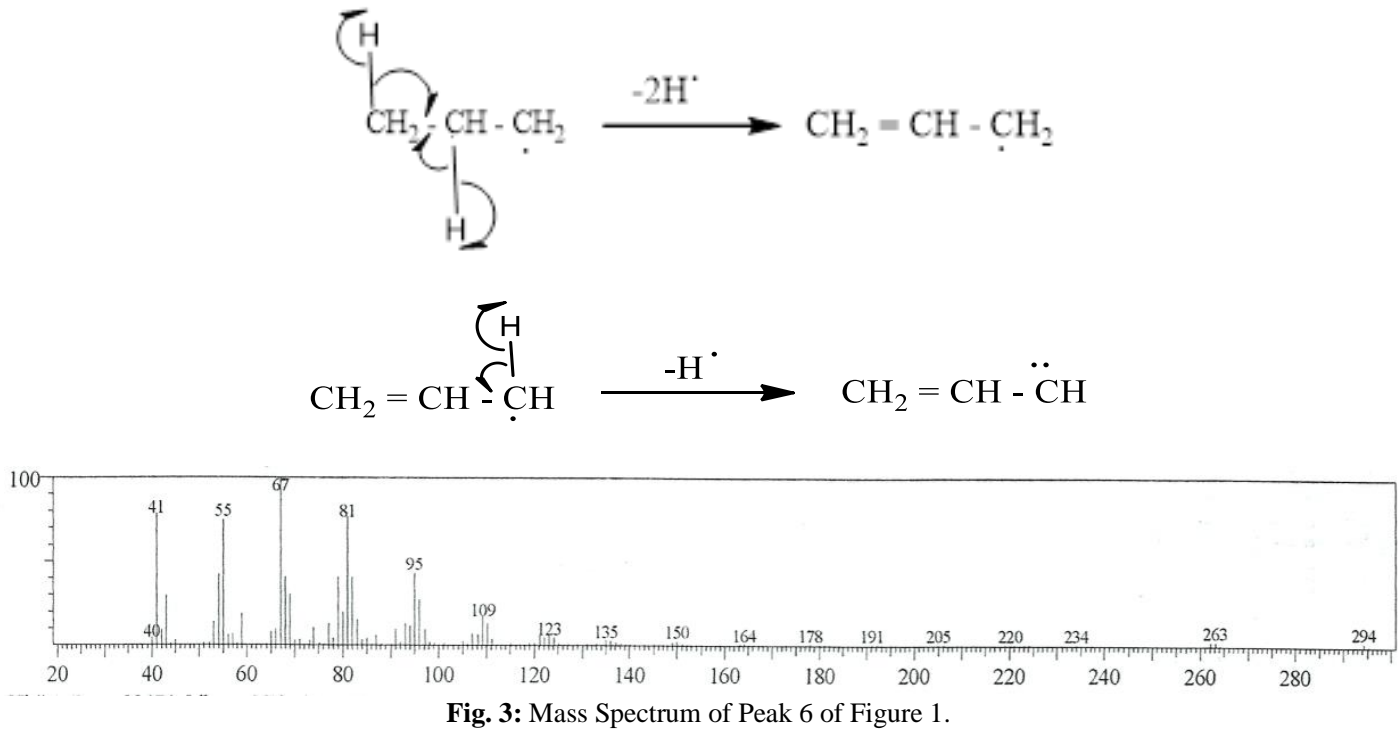

\subsubsection{Fragmentation pattern of 9, 12- Octadecadienoic acid methyl ester (C19H34O2)}

The molecular structure of 9, 12- Octadecadienoic acid methyl ester with the molecular weight of 294 as shown in the mass spectrum is shown below.

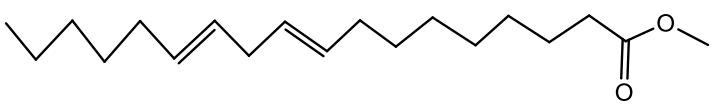

The structure could be rewritten as:

$\mathrm{CH}_{3}-\mathrm{CH}_{2}-\mathrm{CH}_{2}-\mathrm{CH}_{2} \cdot \mathrm{CH}_{2} \cdot \mathrm{CH}=\mathrm{CH} \cdot \mathrm{CH}_{2} \cdot \mathrm{CH}=\mathrm{CH} \cdot \mathrm{CH}_{2}-\mathrm{CH}_{2}-\mathrm{CH}_{2}-\mathrm{CH}_{2}-\mathrm{CH}_{2}-\mathrm{CH}_{2}-\mathrm{CH}_{2}-\mathrm{C}-\mathrm{OCH}_{3}$

The mass of each fragment lost and the mechanisms in the fragmentation pattern of 9,12 -Octadecadienoic acid methyl ester is describe below.

There is a loss of methoxy group to obtain an ion with $\mathrm{m} / \mathrm{z}$ of 263

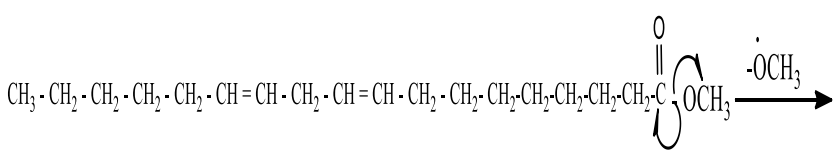

$\mathrm{CH}_{3}-\mathrm{CH}_{2}-\mathrm{CH}_{2}-\mathrm{CH}_{2}-\mathrm{CH}_{2}-\mathrm{CH}=\mathrm{CH} \cdot \mathrm{CH}_{2}-\mathrm{CH}=\mathrm{CH}-\mathrm{CH}_{2}-\mathrm{CH}_{2}-\mathrm{CH}_{2}-\mathrm{CH}_{2}-\mathrm{CH}_{2}-\mathrm{CH}_{2}-\mathrm{CH}_{2}-\mathrm{C}$

9, 12-octadecadienal ion (m.wt 236)

When the loss of an ethylene group and addition of hydrogen ion occurs is to gain an ion with $\mathrm{m} / \mathrm{z}$ of 234

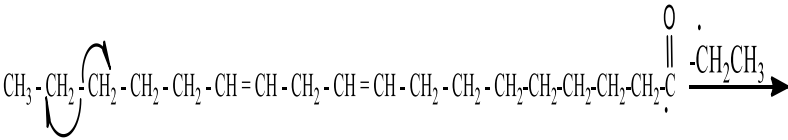

$\mathrm{CH}_{2}-\mathrm{CH}_{2}-\mathrm{CH}_{2}-\mathrm{CH}=\mathrm{CH}-\mathrm{CH}_{2}-\mathrm{CH}=\mathrm{CH}-\mathrm{CH}_{2}-\mathrm{CH}_{2}-\mathrm{CH}_{2}-\mathrm{CH}_{2}-\mathrm{CH}_{2}-\mathrm{CH}_{2}-\mathrm{CH}_{2}-\stackrel{?}{\mathrm{C}}$

9, 12-hexadecadienal ion (m.wt 234)

The subsequent loss of a methylene and a methyl groups result in the formation of ion with $\mathrm{m} / \mathrm{z}$ of 220 and 205 respectively.

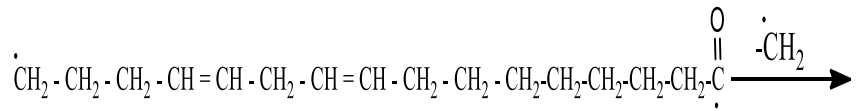

0 $\mathrm{CH}_{2}-\mathrm{CH}_{2}-\mathrm{CH}=\mathrm{CH}-\mathrm{CH}_{2}-\mathrm{CH}=\mathrm{CH}-\mathrm{CH}_{2}-\mathrm{CH}_{2}-\mathrm{CH}_{2}-\mathrm{CH}_{2}-\mathrm{CH}_{2}-\mathrm{CH}_{2}-\mathrm{CH}_{2}-\mathrm{C}$

9, 12-pentadecadienal ion (m.wt 220)
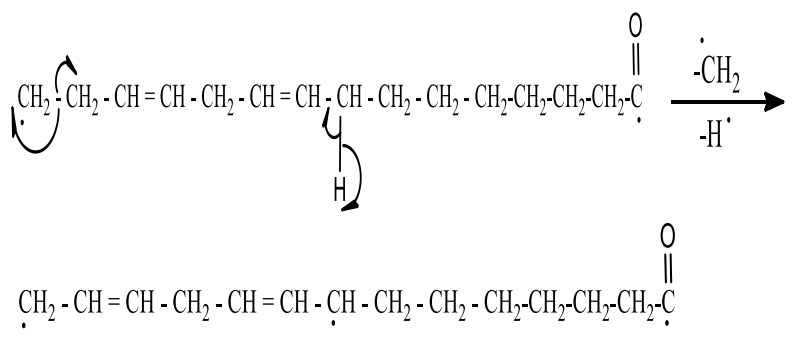

9, 12-butadecadienal ion (m.wt 205)

There is a loss of a methylene group to gain an ion with $\mathrm{m} / \mathrm{z}$ of 191.

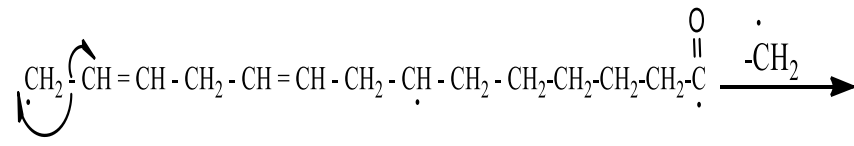




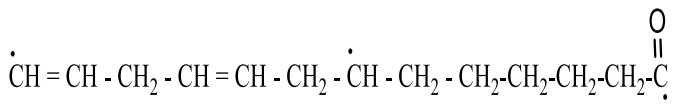

9, 12-tridecadienal ion (m. wt 191)

At this point, there is a loss of an ethylene group that produces an ion with $\mathrm{m} / \mathrm{z}$ of 164

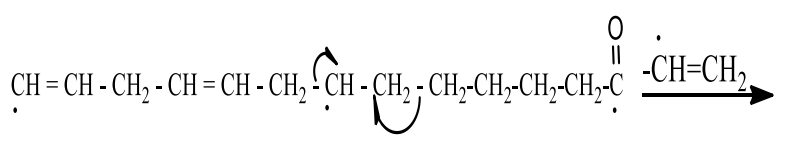

$$
\text { CH }=\mathrm{CH}-\mathrm{CH}_{2}-\mathrm{CH}=\mathrm{CH}-\mathrm{CH}_{2}-\mathrm{CH}_{2}-\mathrm{CH}_{2}-\mathrm{CH}_{2}-\mathrm{CH}_{2}-\stackrel{\text { II }}{\mathrm{C}}
$$

7, 10-undecadienal ion (m. wt 164)

The intermittent loss of methylene and methyl groups gave ions with $\mathrm{m} / \mathrm{z}$ of 150 and 135 respectively.<smiles>C=CCC=CCCCCC(=O)CC(C)C=CCC=CCCCC=CC=O</smiles>

6, 9-decadienal ion (m.wt 150)

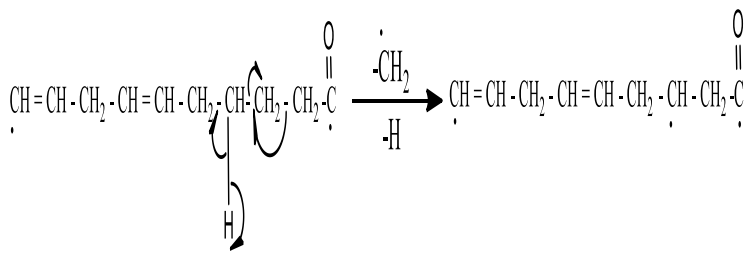

5, 8-nonadienal ion (m.wt 135)

Forming ions with $\mathrm{m} / \mathrm{z}$ of 123 and 109 is becausethere was a loss of methyl and methylene groupswhich occursrespectively.

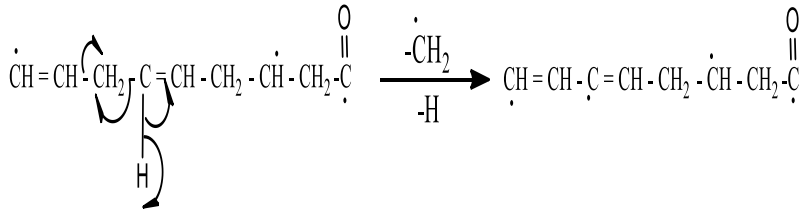

5, 7-octadienal ion (m.wt 123)
There is the formation of an ion with $\mathrm{m} / \mathrm{z}$ of 85 when ethyne group is loss.

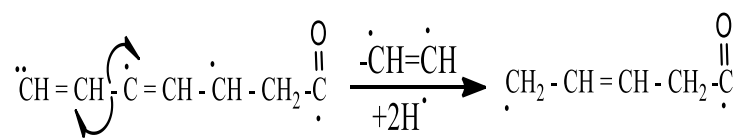

3-pentenal ion (m.wt 85)

The formation of the thermostatically stable ion of the compound with $\mathrm{m} / \mathrm{z}$ of 67 was formed from the combine loss of fragment difference of 4 and 14 as water molecule

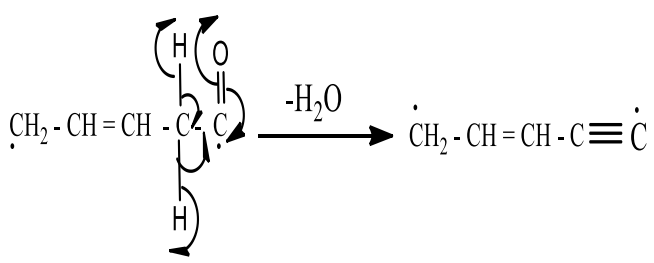

3-penteyne (m.wt 67)

There is a loss of methane group and an addition of hydrogen ion to gain an with $\mathrm{m} / \mathrm{z}$ of 55

$$
\dot{\mathrm{C}} \mathrm{H}_{2}-\mathrm{CH} \stackrel{\mathrm{CH}}{-} \mathrm{C} \equiv \dot{\mathrm{C}} \frac{-\dot{\mathrm{CH}}}{+\mathrm{H}} \rightarrow \mathrm{CH}_{2}-\stackrel{\mathrm{CH}}{-}-\mathrm{C} \equiv \mathrm{C}
$$

Butyne ion (m.wt 55)

The loss of a metylene group and a hydrogen ion gave the final ions of 41 and 40

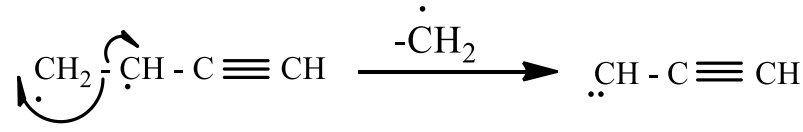

Propyne ion (m.wt 41)<smiles>C#CC#CCCCC</smiles>

Propyne ion (m.wt 40)

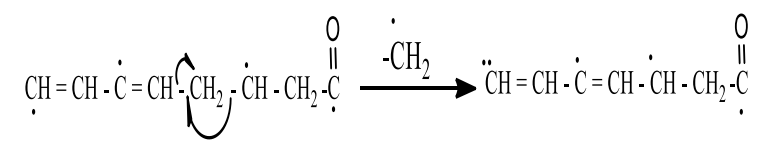

4, 6-heptadienal ion (m.wt 109)

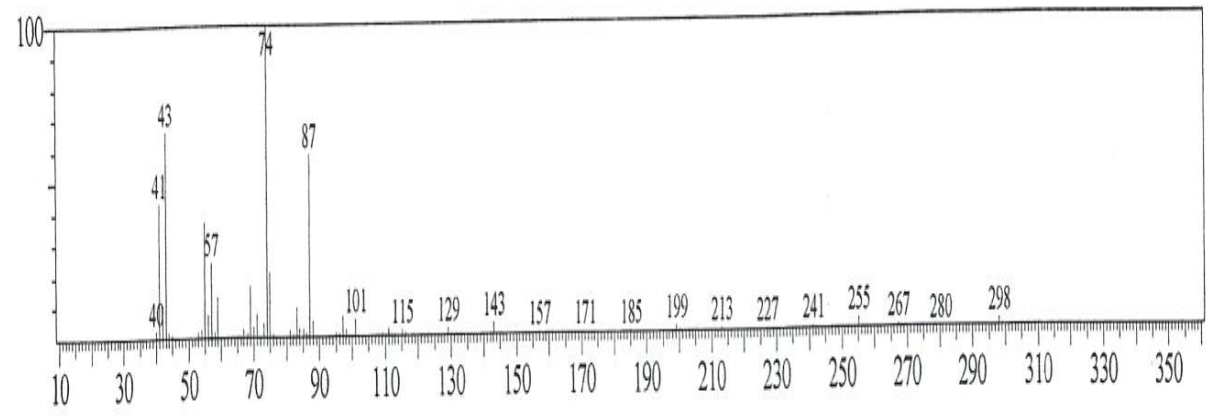

Fig. 5: Mass Spectrum of Peak 8 of Figure 1 


\subsubsection{Fragmentation pattern of octadecanoic acid methyl ester (C19H38O2)}

The molecular structure of Octadecanoic acid methyl ester with the molecular weight of 298 as shown in the mass spectrum is shown below.

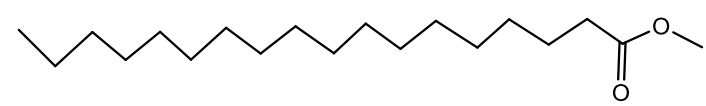

The structure could be rewritten as:

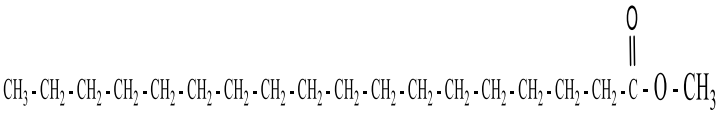

The mass of each fragment lost and the mechanisms in the frag mentation pattern of Octadecanoic acid methyl ester is describe below

A loss of water molecule will give an ion with mass $\mathrm{m} / \mathrm{z}$ of 280 .

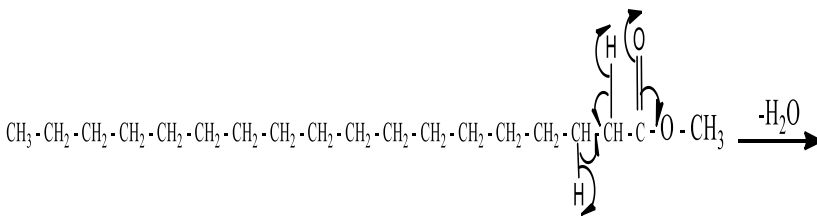

$\mathrm{CH}_{3}-\mathrm{CH}_{2}-\mathrm{CH}_{2}-\mathrm{CH}_{2}-\mathrm{CH}_{2}-\mathrm{CH}_{2}-\mathrm{CH}_{2}-\mathrm{CH}_{2}-\mathrm{CH}_{2}-\mathrm{CH}_{2}-\mathrm{CH}_{2}-\mathrm{CH}_{2}-\mathrm{CH}_{2}-\mathrm{CH}_{2}-\mathrm{CH}_{2}-\mathrm{CH}=\mathrm{CH}-\mathrm{C}-\mathrm{O}-\mathrm{CH}_{3}$

Methyl-2-octadecene ether ion (m.wt 280)

There is a loss of a methylene group and addition of hydrogen ion to form an ion with $\mathrm{m} / \mathrm{z}$ of 267

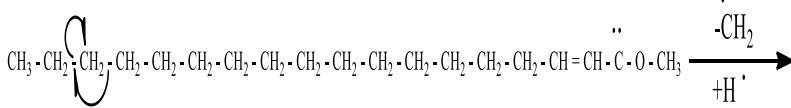

$$
\mathrm{CH}_{3}-\mathrm{CH}_{2}-\mathrm{CH}_{2}-\mathrm{CH}_{2}-\mathrm{CH}_{2}-\mathrm{CH}_{2}-\mathrm{CH}_{2}-\mathrm{CH}_{2}-\mathrm{CH}_{2}-\mathrm{CH}_{2}-\mathrm{CH}_{2}-\mathrm{CH}_{2}-\mathrm{CH}_{2}-\mathrm{CH}_{2}-\mathrm{CH}=\mathrm{CH}-\mathrm{C}-\mathrm{OCH}_{3}
$$

Methyl-2-heptadecene ether ion (m.wt 267)
There could also be a formation of an ion with $\mathrm{m} / \mathrm{z}$ of 225 when a methylene group is lost with an addition of two molecules of hydrogen ion.

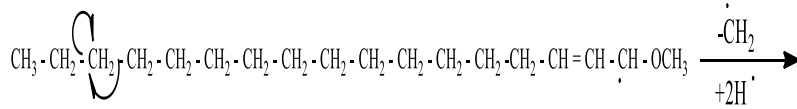

$$
\stackrel{H}{H}
$$

$\mathrm{CH}_{3}-\mathrm{CH}_{2}-\mathrm{CH}_{2}-\mathrm{CH}_{2}-\mathrm{CH}_{2}-\mathrm{CH}_{2}-\mathrm{CH}_{2}-\mathrm{CH}_{2}-\mathrm{CH}_{2}-\mathrm{CH}_{2}-\mathrm{CH}_{2}-\mathrm{CH}_{2}-\mathrm{CH}_{2}-\mathrm{CH}-\mathrm{CH}-\mathrm{CH}-0-\mathrm{CH}_{3}$

Methyl hexadecane ether ion (m.wt 225)

Consecutive loss of 15 molecules of methylene group will produce an ion with $\mathrm{m} / \mathrm{z}$ of 43

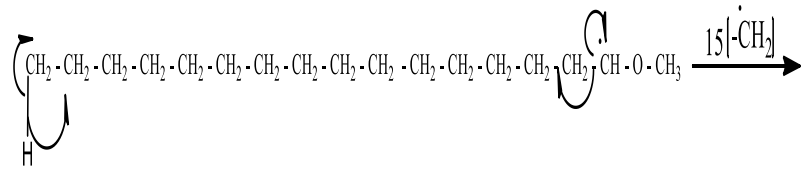

$\mathrm{CH}_{2}-\mathrm{OCH}_{3}$

Dimethyl ether ion (m.wt 43)

Further loss of two molecules and another one molecule of hydrogen ions will give ions with $\mathrm{m} / \mathrm{z}$ of 41 and 40 respectively.

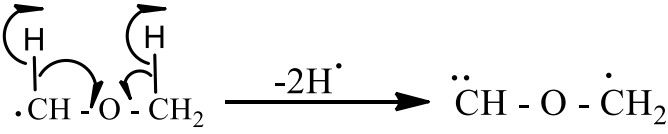

(m.wt 41)

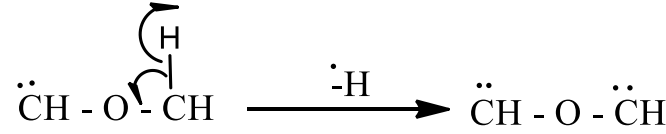

(m.wt 40)

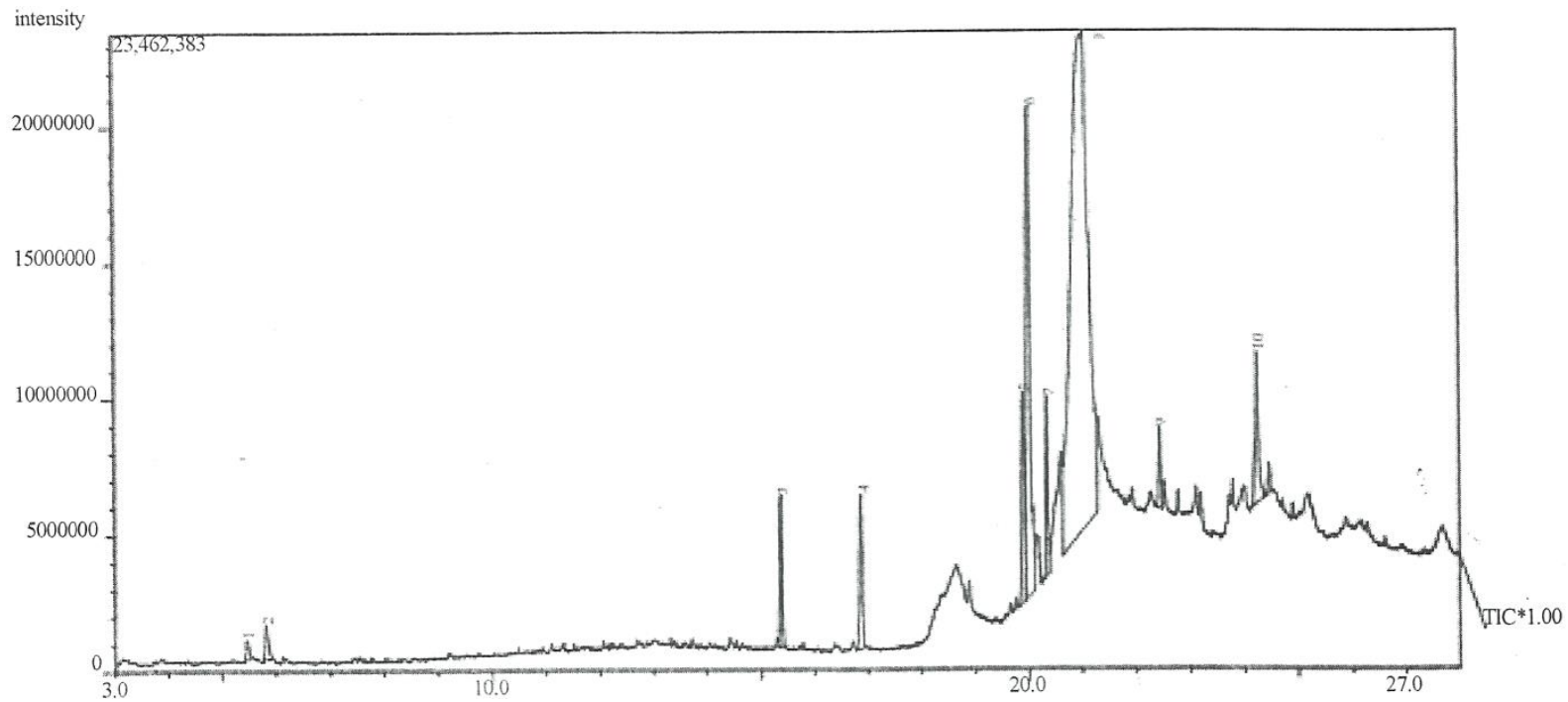

Fig. 6: GC-MS Chromatograms of N-Hexane Leaves Extract Fraction 2. 


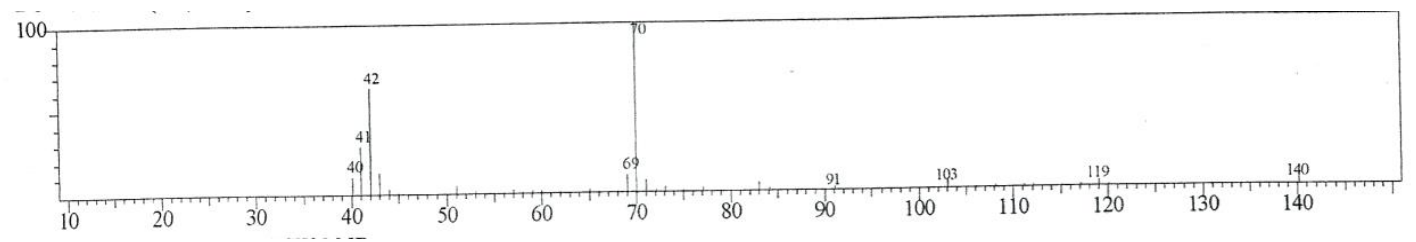

Fig. 7: Mass Spectrum of Peak 1 of Figure 6.

3.4.5. Fragmentation pattern of 2, 2, 4, 4-tetramethyl-1, 2cyclobutanedione (C8H12O2)

The molecular structure of 2, 2, 4, 4-tetramethyl-1, 2cyclobutanedione with the molecular weight of 140 as shown in the mass spectrum is shown below.<smiles>CC1(C)OC(C)(C)O1</smiles>

The ring opening of the structure and could be rewritten as:

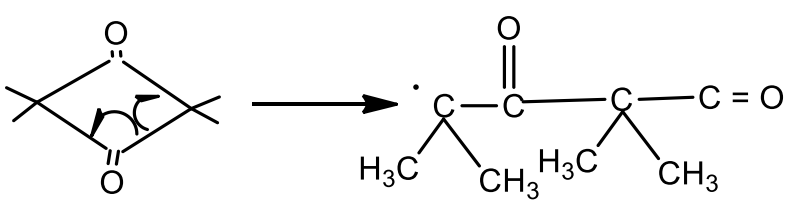

The mass of each fragment lost and the mechanisms in the fragmentation pattern of 2, 2, 4, 4-tetramethy 1-1, 2-cyclobutanedione is describe below.

Here there could be a loss of an oxygen ion and five molecules of hydrogen ion to give an ion with $\mathrm{m} / \mathrm{z}$ of 119 .<smiles>CCC(C)(C)C(=O)C(C=O)(CC)C(=O)O</smiles>

2, 2, 4, 4-tetramethyl-3-butenone ion (m. wt 119)

From the ion with $\mathrm{m} / \mathrm{z}$ of 119 , there could be a loss of a methylene group and two molecules of hydrogen ion to give an ion with $\mathrm{m} / \mathrm{z}$ of 103

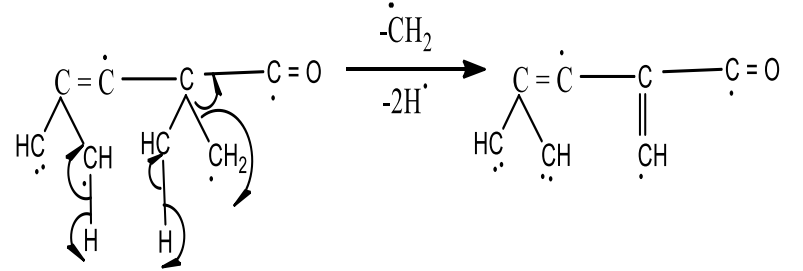

2-methylene-4, 4-dimethyl-3-butenone ion ( $\mathrm{m}$. wt 103) Further loss of a methane group and an addition of hydrogen ion will give an ion with<smiles>O=C(O)C(=O)C#CC#CC(=O)C1CC2CCCCC21</smiles>

2-methylene-4-methyl-3-butynone ion (m.wt 91)

Withdrawing an ethyne group and adding three molecules of hydrogen ion, an ion with $\mathrm{m} / \mathrm{z}$ of 70 will be form as the thermostatically molecular mass ion and major ion of the fragment.

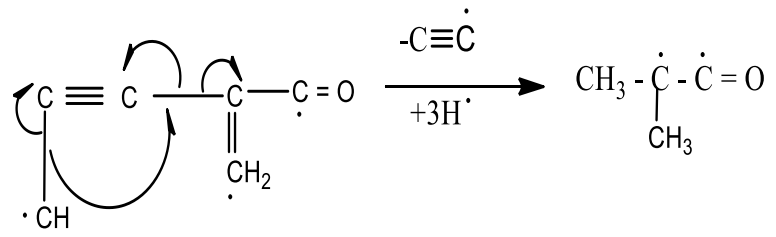

2-methylpropanone ion (m.wt 70)

The loss of a carbonyl group will bring about the formation of an ion with $\mathrm{m} / \mathrm{z}$ of 42

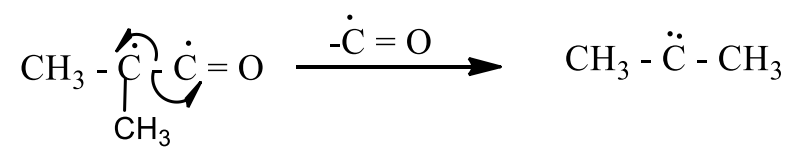

Propane ion (m.wt 42)

Subsequently, the loss of two and one hydrogen ions follows to give ions with $\mathrm{m} / \mathrm{z}$ of 41 and 40 (propa-1.2-diene) respectively
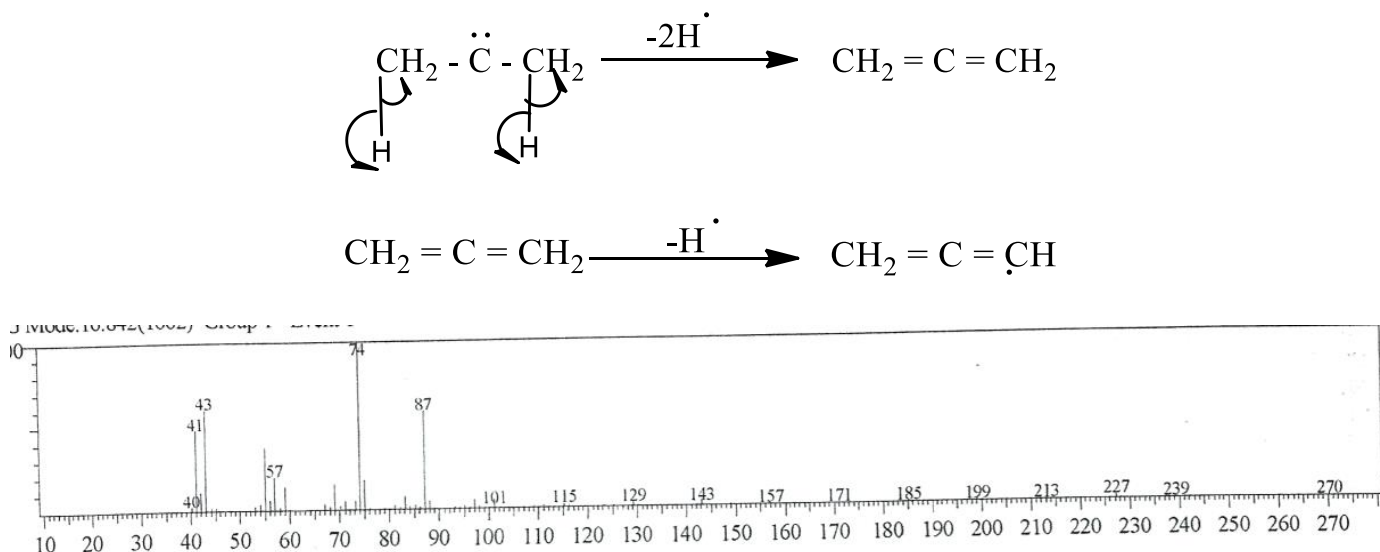

Fig. 8: Mass Spectrum of Peak 4 of Figure 6 


\subsubsection{Fragmentation pattern of pentadecanoic acid-14-methyl methyl ester (C17H34O2)}

The molecular structure of Pentadecanoic acid-14-methyl methyl ester with the molecular weight of 270 as shown in the mass spectrum is shown below.<smiles>COC(=O)CCCCCCCCCCCCC(C)C</smiles>

The structure could be rewritten as:<smiles>COC(=O)CCCCCCCCCCCC(C)C</smiles>

The mass of each fragment lost and the mechanisms in the fragmentation pattern of Pentadecanoic acid-14-methyl methyl ester is describe below

There is a loss of methoxy group to give an ion with $\mathrm{m} / \mathrm{z}$ of 239

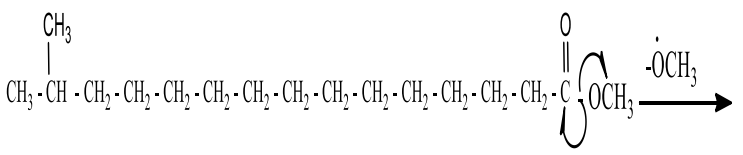<smiles>CC(C)CCCCCCCCCCCCC=O</smiles>

14-methylpentadecanal ion (m.wt 239)

The deduction of mass fragment 12 as loss of methylene group and the addition of two molecules of hydrogen ion will product an ion with $\mathrm{m} / \mathrm{z}$ of 227

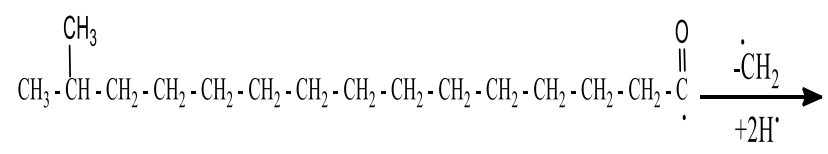<smiles>CC(C)CCCCCCCCCCCCO</smiles>

13-methylbutadecanol ion (m.wt 227)

Further loss of ten molecules of methylene group as subsequently shown in the mass spectrum will produce an ion with mass $\mathrm{m} / \mathrm{z}$ of 87.

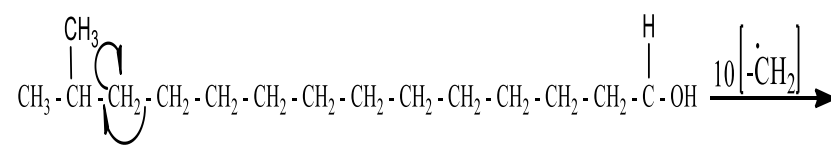<smiles>CC(C)CCO</smiles>

3-methylbutanol ion (m. wt 87)

When a methylene group is detach and an hydrogen ion is added, the thermostatic mass ion of the compound is form with an ion with $\mathrm{m} / \mathrm{z}$ of 74 .<smiles>CCCCCCC(C)C(C)C(C)O</smiles>

2-methylpropanol ion (m. wt 74)

A lossof hydroxyl group produce an ion with $\mathrm{m} / \mathrm{z}$ of 57<smiles>CC(C)CC(O)C(C)C</smiles>

2-methylpropane ion (m. wt 57)

There is a loss of methyl group to form an ion with $\mathrm{m} / \mathrm{z}$ of 42<smiles>CCCCC(C)CC</smiles>

Propane ion (42)

Finally the loss of hydrogen ion will yield an ion with $\mathrm{m} / \mathrm{z}$ of 41

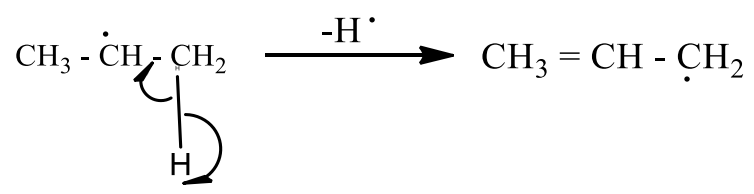

Propene ion (41)

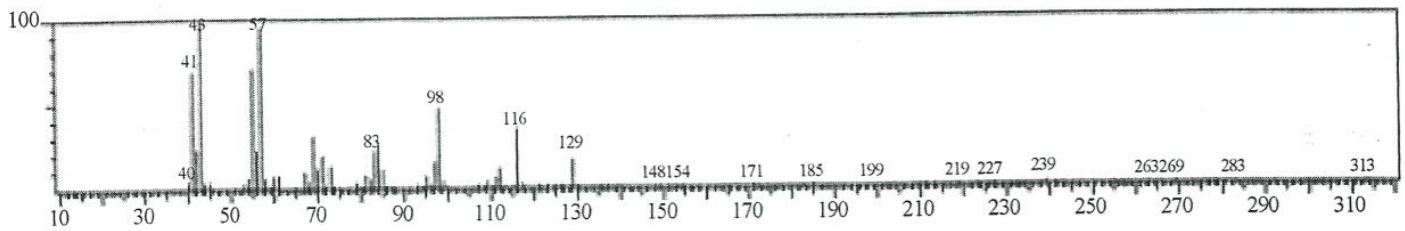

Fig. 9: Mass Spectrum of Peak 9 of Figure 6.

\subsubsection{Fragmentation pattern of hexadecanoic acid-2- hydropropyl ester (C19H36O3)}

The molecular structure of hexadecanoic acid-2-hydropropyl ester with the molecular weight of 313 as shown in the mass spectrum is shown below.

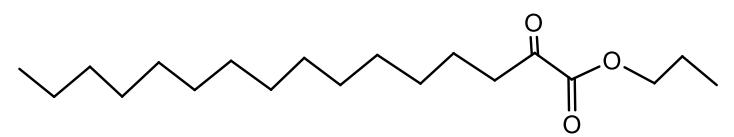

The structure could be rewritten as: 
The mass of each fragment lost and the mechanisms in the fragmentation pattern of hexadecanoic acid-2-hydropropyl ester is describe below.

From an ion with molecular weight of 313 , there could be a loss of $\mathrm{OCH}_{2}$ group to give an ion with $\mathrm{m} / \mathrm{z}$ of 283 .

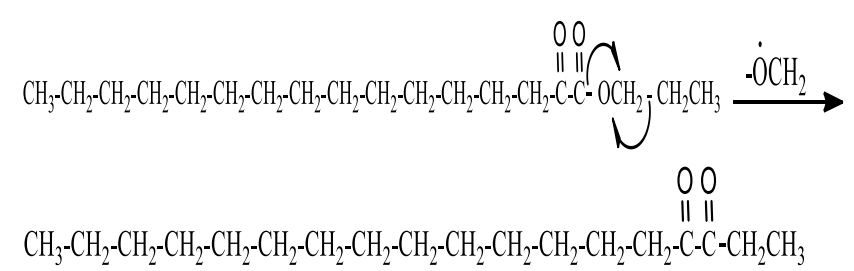

3, 4-dihydrooctadecane (283)

When 4 molecules of hydrogen and oxygen ions are lost, it will give an ion with $\mathrm{m} / \mathrm{z}$ of 263

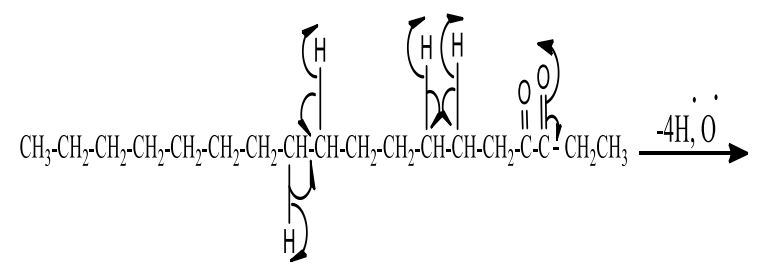

$$
\mathrm{CH}_{3}-\mathrm{CH}_{2}-\mathrm{CH}_{2}-\mathrm{CH}_{2}-\mathrm{CH}_{2}-\mathrm{CH}_{2}-\mathrm{CH}-\mathrm{CH}=\mathrm{CH}-\mathrm{CH}_{2}-\mathrm{CH}_{2}-\mathrm{CH}=\mathrm{CH}-\mathrm{CH}_{2}-\mathrm{C}-\ddot{\mathrm{C}}-\mathrm{CH}_{2} \mathrm{CH}_{3}
$$

4-hydro-6, 10-octadecadiene ion (m.wt 263)

The loss of ethylene group and an addition of 2 molecules of hydrogen ion will further produce an ion with $\mathrm{m} / \mathrm{z}$ of 239

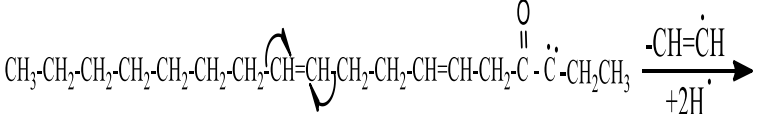

$$
\begin{aligned}
& 0 \\
& \mathrm{CH}_{3}-\mathrm{CH}_{2}-\mathrm{CH}_{2}-\mathrm{CH}_{2}-\mathrm{CH}_{2}-\mathrm{CH}_{2}-\mathrm{CH}_{2}-\mathrm{CH}_{2}-\mathrm{CH}_{2}-\mathrm{CH}=\mathrm{CH}-\mathrm{CH}_{2}-\mathrm{C}-\ddot{\mathrm{C}}-\mathrm{CH}_{2} \mathrm{CH}_{3}
\end{aligned}
$$

4-hydro-6-hexadecene ion (m.wt239)

There was a loss of methylene group and an addition of two molecules of hydrogen ion to give an ion with $\mathrm{m} / \mathrm{z}$ of 227

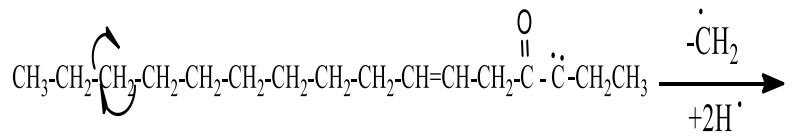

$$
\mathrm{CH}_{3}-\mathrm{CH}_{2}-\mathrm{CH}_{2}-\mathrm{CH}_{2}-\mathrm{CH}_{2}-\mathrm{CH}_{2}-\mathrm{CH}_{2}-\mathrm{CH}_{2}-\mathrm{CH}=\mathrm{CH}-\mathrm{CH}_{2}-\mathrm{C}-\stackrel{\mathrm{C}}{\mathrm{O}} \underset{\mathrm{C}}{\mathrm{C}}-\mathrm{CH}_{2} \mathrm{CH}_{3}
$$

4-hydro-6-pentadecene (m.wt 227)

The loss of the raised 8 molecules of hydrogen ion produce an ion with $\mathrm{m} / \mathrm{z}$ of 219

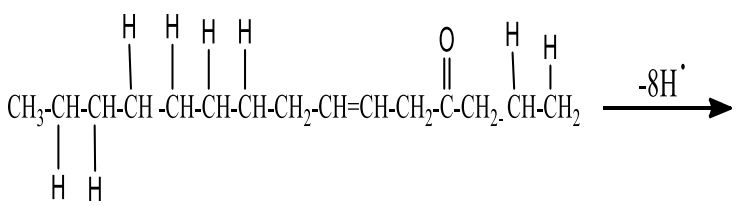

$\mathrm{CH}_{3}-\mathrm{CH}=\mathrm{CH}-\mathrm{CH}=\mathrm{CH}-\mathrm{CH}-=\mathrm{CH}-\mathrm{CH}_{2}-\mathrm{CH}=\mathrm{CH}-\mathrm{CH}_{2}-\mathrm{C}-\mathrm{CH}_{2}-\mathrm{CH}=\mathrm{CH}_{2}$

4-hydropentadeca-1, 6, 9, 11, 13-pentaene (m. wt 219)

To obtain an ion with $\mathrm{m} / \mathrm{z}$ of 199 , an ethylene ion could be lost with an additional six molecules of hydrogen ion

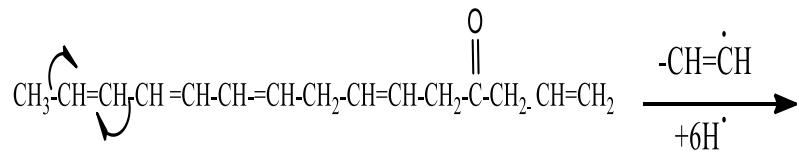<smiles>C=CCC(=O)CCCCCCC</smiles>

4-hydrotridecene (m.wt 199)

When two methylene groupare lost, it produces an ion with $\mathrm{m} / \mathrm{z}$ of 185 and 171 respectively.

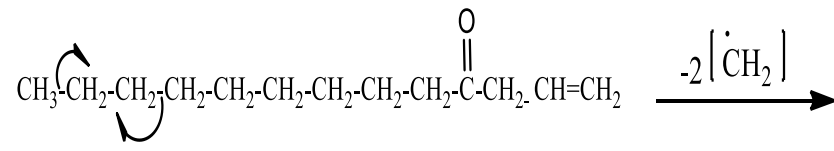<smiles>C=CCC(=O)CCCCCCC</smiles>

4-hydro undecene (m. wt171)

Detaching a hydroxyl group from an ion with $\mathrm{m} / \mathrm{z}$ of 171 will yield an ion with $\mathrm{m} / \mathrm{z}$ of 154

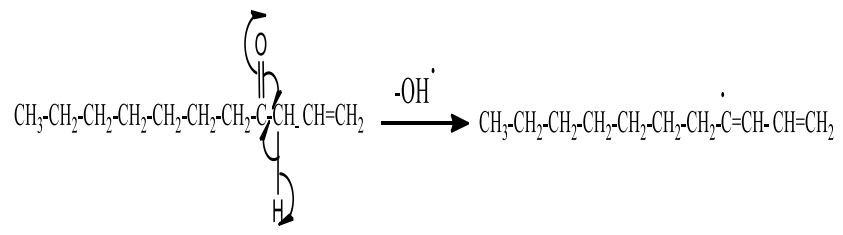

1, 3-undecadiene (m. wt 154)

Withdrawing six molecules of hydrogen ion will gain an ion with $\mathrm{m} / \mathrm{z}$ of 148

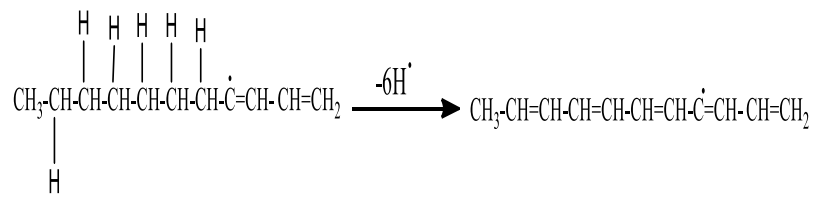

1, 3, 5, 7, 9-undecapentaene(m.wt 148)

The loss of an ethylene group could occur to form an ion wih $\mathrm{m} / \mathrm{z}$ of 129

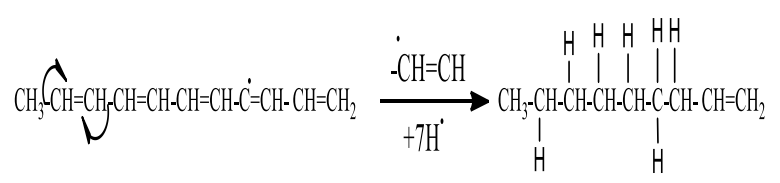

Nonene (m.wt 129)

To form the next ion with $\mathrm{m} / \mathrm{z}$ of 116 , a methine group is loss.

$\mathrm{CH}_{3}-\mathrm{CH}_{2}-\mathrm{CH}_{2}-\mathrm{CH}_{2}-\mathrm{CH}_{2}-\mathrm{CH}_{2}-\mathrm{CH}_{2} \mathrm{CH}_{\bar{j}} \stackrel{-\mathrm{CH}}{\longrightarrow} \mathrm{CH}_{3}-\mathrm{CH}_{2}-\mathrm{CH}_{2}-\mathrm{CH}_{2}-\mathrm{CH}_{2}-\mathrm{CH}_{2}-\mathrm{CH}_{2}-\mathrm{CH}_{2}$ 
Octane ion (m.wt 116)

With the loss of methyl group and three molecules of hydrogen ion, an ion with $\mathrm{m} / \mathrm{z}$ of 98 is form.

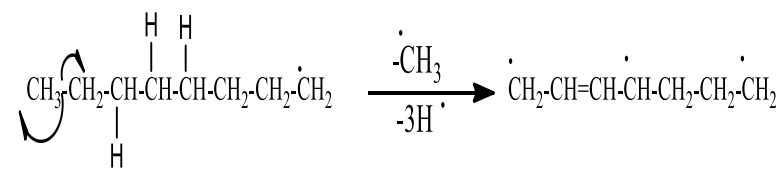

2-heptane ion (m.wt 98)

Now there could be a loss of methylene group and a hydrogen ionto yield an ion with $\mathrm{m} / \mathrm{z}$ of 83

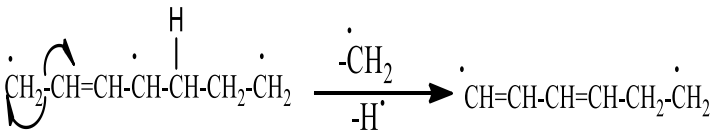

1, 3-hexadiene ion (m.wt 83)

There is a loss of an ethylene group togain an ion with $\mathrm{m} / \mathrm{z}$ of 57

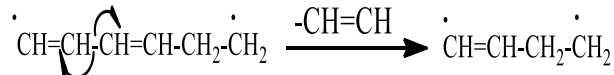

Butene ion (57)

The loss of methylene would be appropriate to form an ion with $\mathrm{m} / \mathrm{z}$ of 43 .

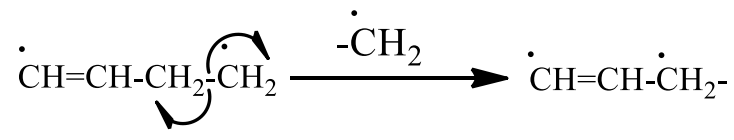

Propene ion (m.wt 43)

Finally, the loss of two and one hydrogen ion one after the other occur to form an ion with $\mathrm{m} / \mathrm{z}$ of 41 and 40 (propyne ions) respectively.

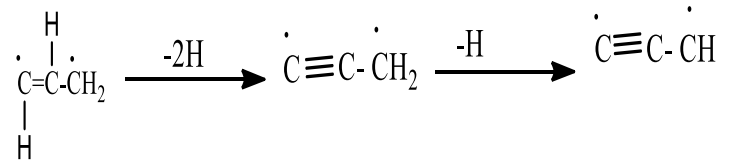

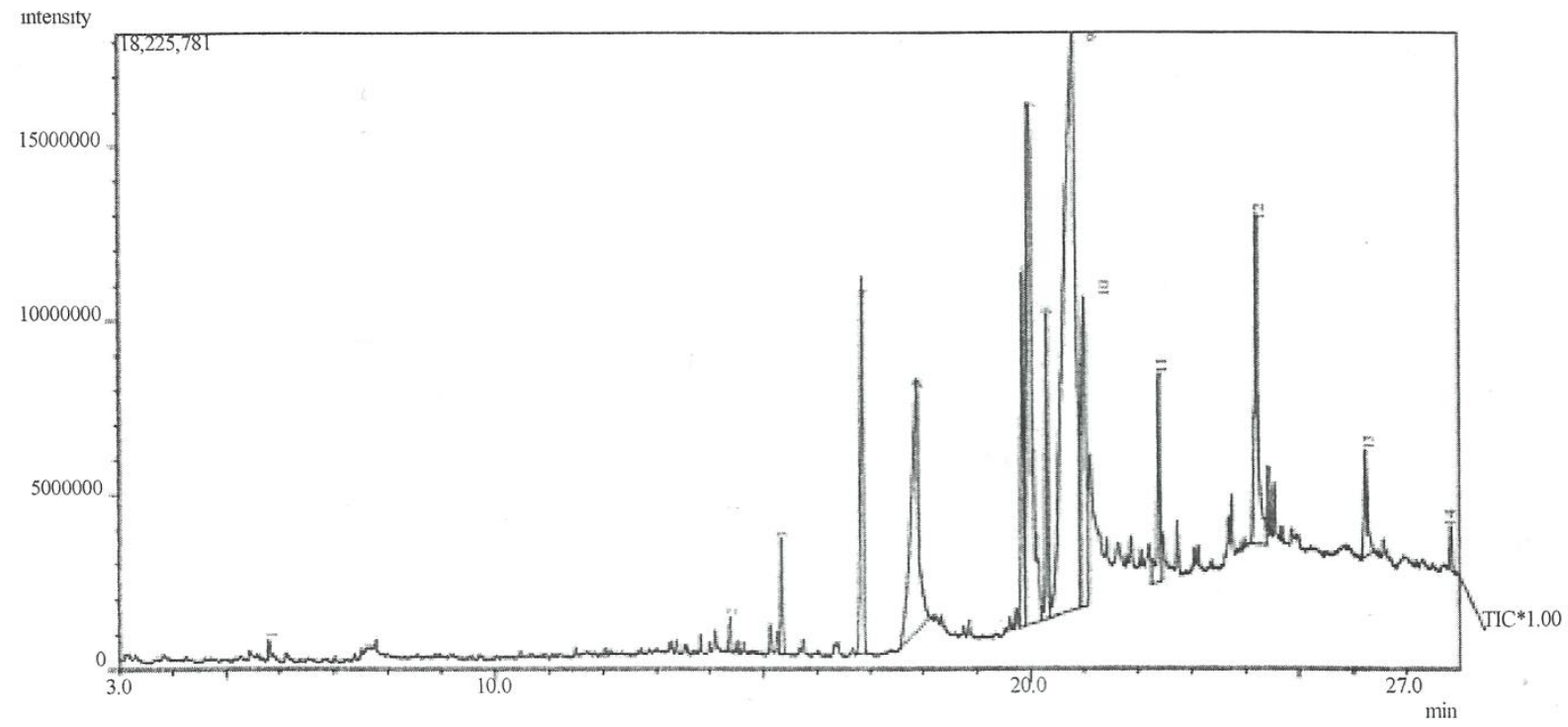

Fig. 10: GC-MS Chromatogram of N-Hexane Leaf Extract Fraction 3

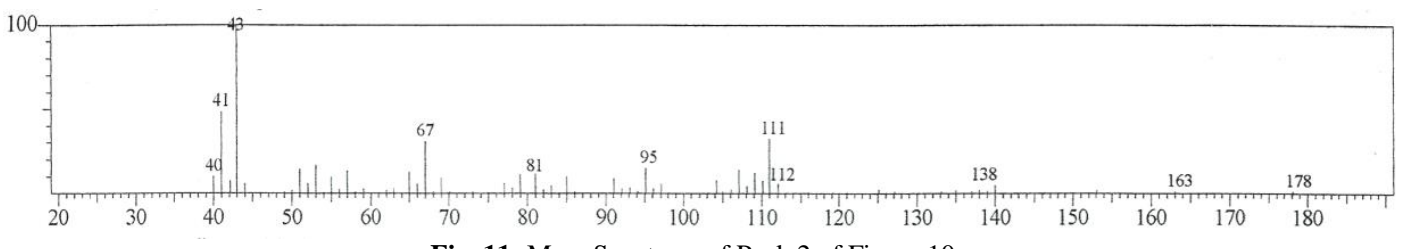

Fig. 11: Mass Spectrum of Peak 2 of Figure 10.

3.4.8. Fragmentation pattern of 2-(4H)-Benzofuranone-5,6,7,7a-tetrahydro- 4,4,7a-trimethyl $\left(\mathrm{C}_{11} \mathrm{H}_{16} \mathrm{O}_{2}\right)$

The molecular structure of $2-(4 \mathrm{H})$-Benzofuran-5,6,7,7a-trimethylwith the molecular weight of 178 as shown in the mass spectrum is given below.

The structure and the ring opening of 2-(4H)-Benzofuranone-5,6,7,7a-tetrahydro-4,4,7a-trimethyl $\left(\mathrm{C}_{11} \mathrm{H}_{16} \mathrm{O}_{2}\right)$

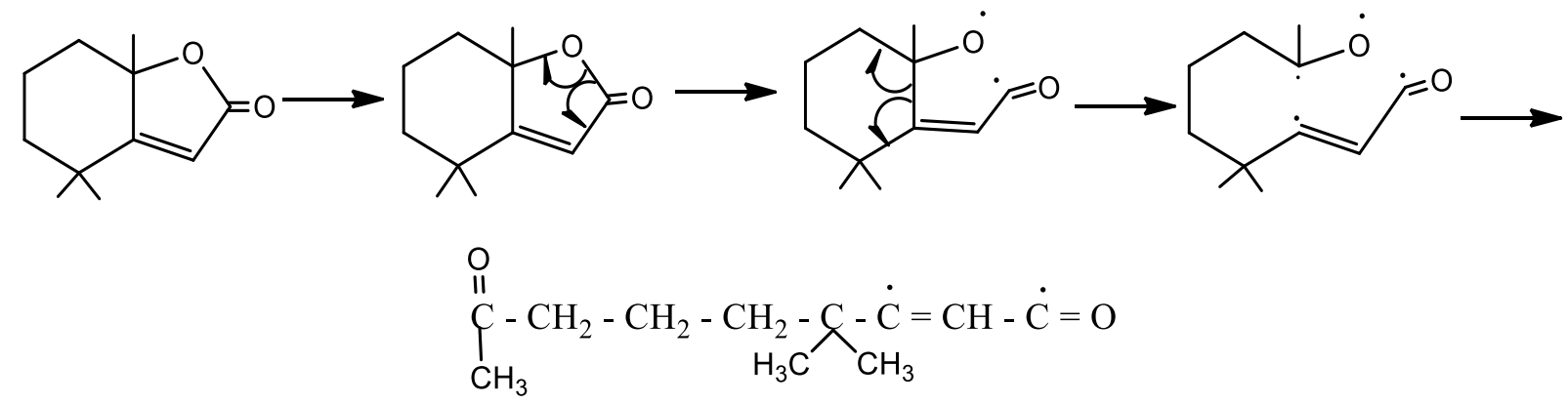


8-hydro-4, 4, 8-trimethyl -2-octenal ion (m.wt 180)

The mass of each fragment lost and the mechanisms in the fragmentation pattern of 2-(4H)-Benzofuran-5,6,7,7a-trimethyl is describe below.

A loss of two molecules of hydrogen ion gave an ion with $\mathrm{m} / \mathrm{z}$ of 178 as shown in the mass spectrum.

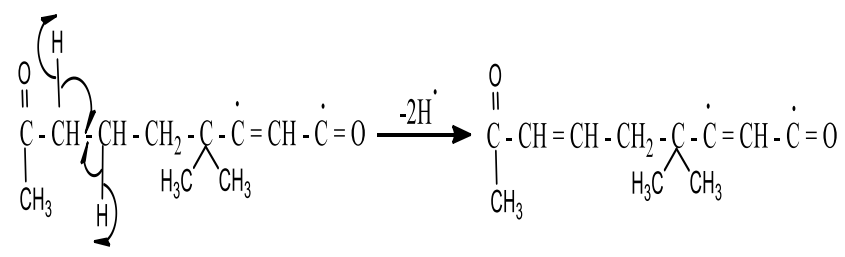

8-hydro-4, 4, 8-trimethyl -2, 5-octadienal ion (m. wt 178)

There after the loss of a methyl group gave an ion with $\mathrm{m} / \mathrm{z}$ of 163<smiles>CC(C)(C=CC=CC=O)CC=CC=CC(=O)C=CCC(C)(C)C=CC=O</smiles>

8-hydro-4,4,dimethyl -2,5-octadienal ion (m.wt 163)

To form the next ion with $\mathrm{m} / \mathrm{z}$ of 138 , an ethylene group was lost

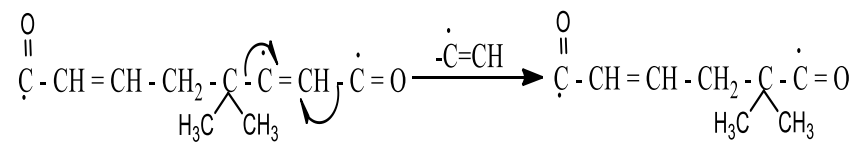

6-hydro-2,2,dimethyl -4-hexenal ion (m.wt 138)

The loss of an ethylene group could occur and an ion with $\mathrm{m} / \mathrm{z}$ of 111 is forms.<smiles>CC(C)(C)C=CC(=O)C=COC(=O)C(C)(C)CCC1CC1C=O</smiles>

4-hydro-2,2,dimethyl -3-butenal ion (m.wt 111)

The loss of another methyl group and a hydrogen ion in the progression of mass of fragment lost, an ion with $\mathrm{m} / \mathrm{z}$ of 95 is form.<smiles>CCCCC(C)C1(C)C(=O)C(C)C1(C)C=O</smiles>

4-hydro-2-methyl-1-3-butadienal ion (m. wt 95)

In this case, a methyl group and a hydrogen ion was gain to yield an ion with $\mathrm{m} / \mathrm{z}$ of 81 .<smiles>CCC(=C=O)C=CC=CC=CC=O</smiles>

4-hydro-1-3-butadienal ion (m.wt 81)

Further withdrawer of oxygen ion and an addition of two molecules of hydrogen ion will give an ion with $\mathrm{m} / \mathrm{z}$ of 67 .

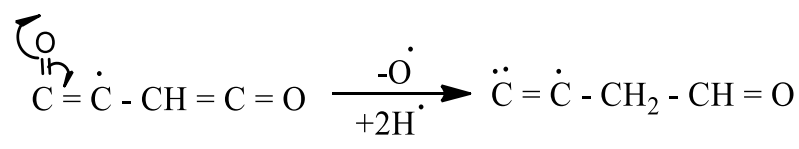

3-butenal ion (m. wt 67)

When an ethylene group is remove and a hydrogen ion is added, an ion with $\mathrm{m} / \mathrm{z}$ of 43 is form.

$$
\ddot{\mathrm{C}}=\dot{\mathrm{C}} \widehat{C} \mathrm{CH}_{2}-\mathrm{CH}=\mathrm{O} \stackrel{-\mathrm{C}=\mathrm{C}}{\longrightarrow} \mathrm{CH}_{2}-\mathrm{CH}=\mathrm{O}
$$

Ethanal ion (m.wt 43)

Finally according to the mass spectrum fragmentation, when two and one molecules of hydrogen ions are loss, ions with $\mathrm{m} / \mathrm{z}$ of 41 and 40(ethenal ion) are form respectively.

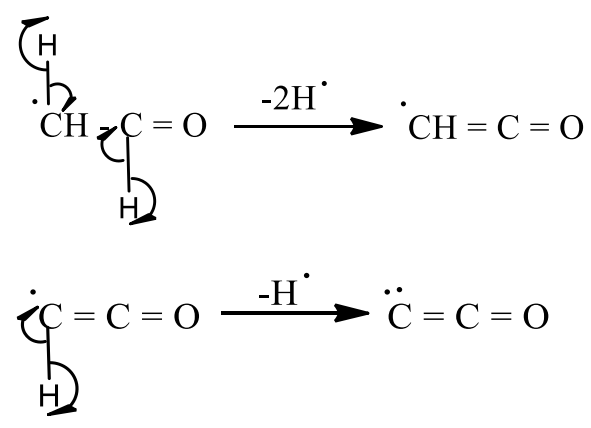

The compounds in table 6 are the result of the GC-MS analysis carried out on the three fractions of the leaf extract. There were some common compounds found in the three fractions that further confirm that it was appropriately pooled from the TLC. These common compounds are the saturated and unsaturated organic acids ester and hydroxides. The presence of Hexadecanoic acid and Hexadecanoicacid methyl ester confirms that the leaves has antioxidant, hypocholesterolemic nematicide, pesticide, antiandrogenic flavor, hemolytic, 5-alpha reductase inhibitor as earlier reported by (Hema et al. 2011, p. 82, Omotoso et al.2014, p. 38). These compounds are likely to affect trypanosomes for they are more susceptible to cellular damages by activated oxygen species $\left(\mathrm{O}_{2}, \mathrm{OH}, \mathrm{H}_{2} \mathrm{O}_{2}\right)$ than mammalian cells (Fairlamb 1982, p. 170). Hexadecanoic acid,9-Octadecenoic acidand 9,12-Octadecadienoic acid produced from their ester have been earlier reported to be present in eucalyptus pulp from GC-MS studies thus agreeing with the result of this work (kilulya et al. 2012, p. 153). 9,12Octadecadienoic acid metyl ester and phytolidentified in the fractions possesses anti-cancer (Hema et al. 2011, p. 82, Omotoso et al 2014, p. 40-44) and 9,12-Octadecadienoic acid however, possesses anti tumour activity (Omotoso et al. 2014) for which such drugs can be screen for their activities (Willaimson\& Scott-Finnigan 1978, p. 735, Barrett \& Barrett 2000, p. 7 Ivan et al. 2014, p. 4609).

Meanwhile, 9, 12-Octadecadienoic acid metyl ester have been found as effective insects repellant, this can be harnessed as insecticide against insect vector diseases. Avoidance of host-vector has been recommended as a method of choice for the control of vector borne diseases (WHO 2015).

It is obvious that the plant has gained popularity in Nigeria to be widely used as traditional medicine justify by the presence of Phytol. For it is use as a precursor for the manufacturing of synthetic form of vitamins $\mathrm{E}$ and $\mathrm{K}_{1}$ that protect animals against status epilepticus induced pilocarpine and decreased the mortality rate (Costa et al. 2012 p. 115). It is further reported as found widespread in nature as part of chlorophyll (Vetter et al. 2012 p. 6103).

A growing evidence have shown to indicate that octadecanamide mediate fundamental neurochemical process including sleep thermoregulation, nociception, prostaglandins and other lipids (Chaturvedi et al.2006 p. 136). Heneicosanoic acid methyl ester and 
tricosanoic acid found in this plant are fatty acids commonly in plant oils and extracts, can be utilized as relaxant. 9,12octadecadienoic acid (antibacterial), octadecanoic acid (antimicrobial, hardener and thickener use as skin cleaner in soap industries) 9,12,15 octadecatrienoic acid methyl ester for antibacterial,anticandidal, antiinflammatory, hypocholesterolemic, cancer preventive, hepatoprotective, nematicide, insectifuge antihistaminic,antiarthritic, anticoronary, antieczemicantiacne, 5alphareductase inhibitor antiandrogenic and2(4H)-Benzofuran5,6,7,7a-tetrahydro-4,4,7a-trimethyl for antimicrobial (Mujeeb 2014, table 6). 2,2,4,4-tetrametyl-1,3-cyclobutanedione is well known building block for the sterically congested system (Brunck 2001, p. 227) These compounds are synergiscally responsible for the activities of the plant which can be harness for the development of our developing countries in the area of pharmacological techniques and economic improvement.

\section{Conclusion}

The results of our finding indicate that the n-hexane extract of $C$. torelliana is a rich source of bioactive agent of natural background, which might have potentials for use in the classification of drugs in pharmaceutical industries. This study has contributed and justifies the claim of the plant as traditional medicine without any adverse side effect as reported in developing countries compare with synthetic drugs. The spectra therein have been identified as shown by the fragmentation patterns and mechanisms as possibly those of the compounds identified which have medicinal and pharmacological properties. In spite of the medicinal importance of C. torelliana, it has short rotation hardwood for variety of products and ornamentals with specific emphasis on existing and emerging markets for revenue generation if domesticated.

\section{References}

[1] Adeniyi BA \&Ayepola OO (2008) the phytochemical screening and antimicrobial activity of leaf extracts of eucalyptus camaldulensis and eucalyptustorelliana / (myrtaceae). Research Journal of Medicinal Plants 2, 34-38. https://doi.org/10.3923/rjmp.2008.34.38.

[2] Adeniyi AG, Odufowoke RO \&Olaleye SB (2006) Antimicrobial and gastroprotective properties of eucalyptus torelliana / (myrtaceae) crude extracts. International Journal of Pharmacology 2,362-365. https://doi.org/10.3923/ijp.2006.362.365.

[3] Alian AG, Felician A, Boniface Y, Alian KY, Chantal M \& Dominique S (2012) Chemical and biological investigation of leaves of eucalyptus torellianaessentialoil from Benin. International Research Journal of Biological Sciences 15, 6-12.

[4] Atlas RM (1995) Microorganisms in our World $2^{\text {nd }} e d n$. Mosby Publishers Inc. Baltimore, pp. 765.

[5] Azra A, Ekwenchi MM, Dashak DA \&Dildar A (2012) Gas Chromatography-Mass Spectrometry (GC-MS) analysis of Phthalate isolate in n-hexane extract of Azadirachta A. Juss(Neem) leaves.Journal of American Science 8(12), 146-155.

[6] Barret SV and Barret MP (2000) Anti-sleeping sickness drugs and cancer. Chemotherapy and Parasitology Today 16, 7-9. https://doi.org/10.1016/S0169-4758(99)01560-4.

[7] Brunck JS, Koch A, Grzegorz M, Lehnhoff S, Margaretha P, Prakash GKS, Rasul G, Bau R \&Olah GA (2001) 1,2 addition of TMSCF3 TMS-CN toserially crowded 2,2,4,4-tetramethyl-1-3cyclobutanedione. Journal of Indian Institute of Science 81, 227 237

[8] Bruneton J (1999) Pharmacognosy: Phytochemistry. In Medicinal Plants $2^{\text {nd }}$ edn. London Intercept Ltd pp. 555-559.

[9] Bwai MD, Afolabi M, Odukomaiya D, Ikokoh P \& OrishadipeA (2014) Proximate composition, mineral and phytochemical constituents of Eleusinecoracana (finger millet).International Journal of $\begin{array}{llll}\text { Advance } & \text { Chemistry } & \text { 2(2), } & 171-174\end{array}$ https://doi.org/10.14419/ijac.v2i2.3496.

[10] Chaturvedi $S^{1}$, Driscoll WJ, Elliot BM, Faraday MM, Grunberg NE\& Mueller GP (2006) In vivo evidence that N-oleoylglycine act independently of its conversion to oleamide.Prostaglandins and $\begin{array}{llll}\text { other Lipid } & \text { Mediat } & \text { 81(3-4), } & \text { 136-149. }\end{array}$ https://doi.org/10.1016/j.prostaglandins.2006.09.001.
[11] Costa JP ${ }^{1}$, Ferreira PB, De Sousa DP, Jordan J\&Freitas RM (2012) Anticonvulsant effect of phytol in a pilocarpine model in mice. $\begin{array}{llll}\text { Neuroscience letter523 } & \text { (2), 115-118. }\end{array}$ https://doi.org/10.1016/j.neulet.2012.06.055.

[12] Dashak D A \&Ano J (2007) Chemical composition and phytochemical studies of Crinum zeylanicum. Journal of Sciences Engineering and Technology 14 (2), 7355-7365.

[13] Dashak D A, Daben J M,Olaoye FM, Ogunbiade AT\&OgboleE (2016) Evaluation of the essential oils constitutes from the leaves, seed buds and fruits of EucalytustorellianaF. Muel plant by Gas Chromatography- Mass Spectral analysis. IOSR-Journal ofApplied Chemistry 9 (10), 45-60.

[14] Fairlamb AH (1982) Trends Biochemistry Science: Difluoromethyornithine and the rationale development of polyamine antagonism in the cure ofprotozoa infection. In Mechanism of Drug Action, Academic press, USA, pp.159-173.

[15] Farah A, Fechtal M, ChouchA\&Zarira S (2002) The Essential oil of Eucalyptus camaldulensis and its natural hybrid (clone 583) from Morocco. Flavour Fragrance Journal 17, 395-397. https://doi.org/10.1002/ffj.1114.

[16] Ivan S, Pablo T, Juan CE, Natalia Q, Mauricio AC, Juan V, Christian E, Angelica F, Ricardo AT, Juan DM, Rodrigo L, Bruce KC, Ramon JE \& Christian OS (2014) 2-Phenylaminonaphthoquinones and related compounds: Synthesis, trypanocidal and cytotoxic activities. In Bioorganicand Medicinal Chemistry 22, 4609-4620. https://doi.org/10.1016/j.bmc.2014.07.030.

[17] Glasby JS (1999) Dictionary of Plants Containing Secondary Metabolites. Taylor and Francis Ltd, Londonpp. 125-225.

[18] Harborne JB (1984). Phytochemical methods. A guide to modern techniques of plant analysis. $2^{\text {nd }}$ edn. Chapman and Hall, London,pp 1, 11. https://doi.org/10.1007/978-94-009-5570-7.

[19] Hema R, Kumaravel S \&Lagusundaram A (2011). GC/MS determination of bioactive components of Murrayakoenigii. Journal of American Science 7 (1), 80-83.

[20] Kilulya KF, Msagati TAM, Mamba BM, Ngila JC \& Bush T (2012) Ionic liquid-liquid extraction and supported liquid membrane analysis of lipophilic wood extractives from dissolving pulp. Chromatographia 75, 513-520. https://doi.org/10.1007/s10337-012-2225-5.

[21] Lee TA (1998) A Beginner's Guide to Mass Spectral Interpretation. JohnWiley and Sons Inc. (NY) pp 1-21.

[22] Lister PD, Wolter DJ \& Hanson ND (2009) Antibacterial-resistant Pseudomonas aeruginosa: Clinical impact and complex regulation of chromosomally encoded resistance mechanisms. Clinical Microbiology Revision 22(4), 582-610 https://doi.org/10.1128/CMR.00040-09.

[23] Mujeeb F, Bajpai P \&Pathak N (2014) Phytochemical evaluation, antimicrobial activity and determination of bioactive compounds from leaves of Aeglemarmelos. BioMed Research InternationalAvailable at: http://dx.doi.org/10.1155/2014/497606 (accessed 25 March 2016). https://doi.org/10.1155/2014/497606.

[24] Ochei J\&Kochatkar A (2007) Medical Laboratory Science, Theory and Practice.Tata McGraw-Hill Ltd, pp. 795-817.

[25] Ogbole E, Dashak DA,Nvau JB, Daben MR, Abongaby G, Obaloto OB, Oladipo OO, Igweh AC (2016) Phytochemical screening and in vitro evaluation of the antitrypanosomal action of the methanolic leaf extract ofCorymbiatorelliana. International Journal of Ethno$\begin{array}{lll}\text { medicine and } & \text { Pharmacology } & \text { 20-29. }\end{array}$ https://doi.org/10.14194/ijep.3.1.3.

[26] Ololade ZS and Olawore NO (2013) Chemistry and medicinal potentials of the seed essential oil of Eucalyptus torellianaF.Muellgrown in Nigeria. Global Journal of Science Frontier Research Chemistry 13(3), 1- 11.

[27] Omotoso AE, Eseyin OO \& Suleiman M (2014) Phytochemical analysis ofCnidoscolusaconitifolius(Euphorbiaceae) leaf with spectrometric techniques. Nigerian Journal of Pharmaceutical and Applied Science Research 3 (1), 38-49.

[28] Roopashree TS, Dang R, Rani SRH, Narendra C (2009) Antibacterial activity ofantipsoriatic herb: Cassia tora, MomordicaCharantia and Calendula officinalis. International Journal of Applied Research in Natural products 1(3), 20-28.

[29] Sanchez NR, Garcia DA, Shiavini MS, Nakamura CV \&Filho BPD (2005) an evaluation of antibacterial activities of $P$ sidiumguajava. Brazilian Journal of biotechnology48, 429-436.

[30] Segelman AB, Farnsworth NR, and Quimby MD (1969) Biological and phytochemical evaluation of plants 111: False-negative saponins test results induced by the presence of tannins.Lloydia 32, 5255.

[31] Silverstein RM, Bassler GC \& Morrill TC (1974) Spectrometric Identification of Organic Compounds. $3^{\text {rd }}$ edn.John Wiley and Sons Inc. (NY) pp 41-71. 
[32] Sofowora A (1982) Medicinal plants and traditional medicine in Africa. John Wiley and Sons Ltd, New York, pp.54-56.

[33] Thomas KW (1975) Principles and Techniques of Practical Biochemistry. (Williams BL \& Wilson K ed.), Edward Arnold Ltd, London pp52-98.

[34] Trease GE \& Evans MD (1989) A textbook of Pharmacognosy. $13^{\text {th }}$ edn. Braillier, Tindaland Caussel, London, pp. 244-248.

[35] Vagahasiya YNR, Chanda S (2008) Antibacterial and preliminary phytochemical and physiochemical analysis of eucalyptus citriodora HK leaf.Natural Product Research 22(9), 754-762. https://doi.org/10.1080/14786410701628788.

[36] Vetter $W^{1}$, Schröder M\&Lehnert K (2012) Differentiation of refined and virgin edible oils by means of the trans- and cis-phytol isomer distribution.Journal of Agriculture and Food Chemistry 60(24), 6103- 6107. https://doi.org/10.1021/jf301373k

[37] Vishnoi NK (1979) Advance Practical Organic Chemistry.Vikas Publishing House PVT Ltd pp. 40-42.

[38] Wall ME, Kreider MM, Krewson CF, Eddy CR, Williams JJ, Cordel DS \& Gentry HS (1954) Survey of plants for steroidal sapogenins and other constituents. Journal of AmericanPharmaceutical Association 43, 1-7. https://doi.org/10.1002/jps.3030430102.

[39] Williamson J \& Scott-Finnigan TJ (1978) Trypanocidal activity of antitumour antibiotics and other metabolic inhibitors. Antimicrobial Agents andChemotherapy 13,735-744. https://doi.org/10.1128/AAC.13.5.735.

[40] World Health Organization (2001) Global Strategy for Containment of Antimicrobial Resistance. Available at: www.who.int/emc- document/antimicrobial resistance/docs/global start.pdt(accessed 23 March 2015).

[41] World Health Organization (2016) African Trypanosomiasis (Sleeping sickness). Fact sheet, no. 259. Available at: www.who.int/mediaccentre/factsheets/fs259/en/(accessed $25 \mathrm{Au}$ gust 2016). 